\title{
Management Control and Takeover Premiums
}

\author{
Trevor W. Chamberlain ${ }^{1}$ \& Maxime Fabre ${ }^{1}$ \\ ${ }^{1}$ DeGroote School of Business, McMaster University, Hamilton, Canada \\ Correspondence: Trevor W. Chamberlain, Professor of Finance and Business Economics, DSB 304, DeGroote \\ School of Business, McMaster University, 1280 Main Street West, Hamilton, ON L85 4M4, Canada. Tel: \\ 905-525-9140, Ext. 23980.
}

Received: June 5, 2016

Accepted: June 24, 2016

Online Published: July 4, 2016

doi:10.5430/ijfr.v7n4p66

URL: http://dx.doi.org/10.5430/ijfr.v7n4p66

\begin{abstract}
This study examines the relationships between the management control strength of target and acquiring firms, and takeover premiums. It uses a scorecard system, which aggregates the scores of twelve variables reflecting corporate governance quality and ownership structure characteristics, to define management control strength. Using descriptive statistics and regression analysis, a sample of eighty-one North American publicly traded companies that were in involved in M\&A transactions between 2010 and 2013 is examined. Acquirers were found to have paid significantly higher premiums when at least half of the directors sitting on target boards held multiple directorships. Additionally, when at least half of the directors sitting on acquirers' boards held multiple directorships, acquirers paid significantly lower premiums. The study also found that when an acquirer's management control is strong and a target's management control is weak, the size of the premium is significantly lower than the sample average. This could be explained by the acquirer's greater ability to negotiate deal premiums when its management control is strong and by a lower perceived value of the target firm when target management control is weak. When a target management control is strong and acquirer management control is weak, and when both target and acquirer's management control is either strong or weak, the premiums paid are not significantly different from the sample mean. These results provide the first step towards developing an investment screening tool for companies involved in M\&A transactions.
\end{abstract}

Keywords: takeover premiums, management control, corporate governance, target firms, acquiring firms, scorecard

\section{Introduction}

This study examines the relationship between management control of companies involved in M\&A transactions and takeover premiums. Premiums are often justified by growth opportunities and creation of synergies. However, some evidence demonstrates that these premiums might result from overpayments, which destroy value to shareholders. Based on these findings, we believe that developing an understanding of the sources of premiums would allow us to determine whether transaction premiums are overpayments (value destroying to shareholders), fair payments or underpayments.

There is growing evidence that premiums are affected by a variety of governance and ownership concentration variables. No study to date has brought these variables together into a single framework which aims at explaining what justifies the payment of premiums. The term "management control" is used in this study as a generic term to refer to a group of corporate governance and ownership structure variables.

We attempt a new approach to research on takeover premiums by proposing a scorecard system to evaluate the strength of the management control of companies. We assess our sample companies' management control strength and analyze 42 recent North American transactions using descriptive statistics and regression analysis to uncover significant relationships between management control characteristics and takeover premiums.

The remainder of this paper is organized as follows: Section 1 summarizes the findings from previous studies as to what factors were found to affect takeover premiums and what constitutes higher management control quality. An understanding of the existing literature allows us to identify more precise research questions and to formulate our empirical methodology (Section 2). Our analysis is presented in Section 3. Based on the outcome of our analysis, Section 4 proposes interpretations of the results and their practical consequences. 


\section{Literature Review}

In this section, we examine the existing literature to deepen our understanding of the constituents of takeover premiums. First, we focus our research on the relationship between takeover premiums and shareholder value. Second, we look at factors that have been shown to be related to takeover premiums. From these findings, we define management control and examine further company features that are related to transaction premiums. Then, we identify a way to extend the literature, which also has practical implications for investors. We conclude Section 1 by outlining our research questions.

\subsection{Takeover Premiums and Shareholder Value}

There is a premium when the acquiring firm pays (in shares and/or stock) a greater amount than the market value of the target firm prior to the merger. Melicher and Nielsen (1973) analyzed the premiums paid by companies and assessed the extent to which "synergy" was a correct justification of the premiums. Synergy relates to enhancing the value of the new post-merger firm by taking advantage of economies of scale, increased operational efficiencies or financial benefits. Melicher and Nielsen's main finding was that the synergies expected from mergers were not significant rationalizations for the premiums paid by acquiring firms. As a result, they established that there should be some factors taken into account by the firm's management when determining the amount to be paid as a premium; otherwise, we would witness an overpayment and the premium would destroy value for the acquiring company's shareholders.

Over the four decades following Melicher and Nielsen, an extensive literature grew up on the impact of takeover premiums on value creation. However, two opposing perspectives persist. On the one hand, studies show that premiums destroy value. Hitt, Krishnan and Park (2007) demonstrated by analyzing 174 transactions that occurred in the 1990s, that high premiums were a liability that needed to be recovered by performance enhancement. The search for efficiencies to pay back the premiums often led to workforce reduction (cutting costs), which caused poor post-merger performance and value destruction.

Devers, Haleblian, McNamara and Yoder (2013) defend this thesis by stating that acquiring CEOs tend to take advantage of short term post-merger market increases to exercise their stock options. Their actions and the premiums paid do not reflect the potential long term value growth of the newly formed entity. CEOs do not "walk their talk", which suggests that premiums could be used as a tool for personal enrichment, deceiving stakeholders and leading to value destruction.

On the other hand, using 396 public mergers and acquisitions in the United Kingdom over 19 years, from 1985 to 2004, Hamerman (2007) argues that firms involved in mergers and acquisitions with high premiums perform better post-transaction than those with low premiums. Acquisition premiums would therefore reflect management's confidence in creating value with the transaction.

This thesis is supported by Laamanen (2007), who demonstrated that premiums paid were not related to abnormal negative returns. His findings suggest that a high overall price of the target contributes to negative returns, but the premium paid is not statistically related to negative returns and does not reflect management's poor decision-making skills. Premiums could therefore be a measure of expected future returns for the post-merger firm, as opposed to an overpayment destroying value to shareholders.

The above studies established that takeover premiums are related to value creation post-merger. Thus, they are an important parameter to consider for shareholders, investors and analysts building expectations of future results, even though the direction of the correlation between premiums and value creation is not clearly defined. Being able to understand the components which explain the acquisition premiums would be important information to have for investment purposes. One would then be able to determine whether a premium is an overpayment, a fair payment or an underpayment in relation to expected value creation. Conclusions differ due to the choice of variables considered in the research, the time frame used, the number of transactions analyzed and the type of mergers or acquisitions. In the following section, we search the existing literature for variables that are known to be correlated with premiums.

\subsection{Factors Known to Affect Premiums}

\subsubsection{Regulations}

Regulations have historically been found to be significantly related to takeover premiums. The literature shows that both positive and negative correlation exists, depending on the time span of the research, the scope of the data and the type of merger-related regulation analyzed. 
In 1987, new statutes regulating takeovers were adopted in the State of New York. Target firms gained power in takeover attempts, benefitting from non-negotiable increases in takeover costs. Studies found that such regulations tend to amplify the premiums paid by acquiring firms and that, despite these higher premiums, target firms' shareholders are harmed in the long run when payments are made in stock (Schumann, 1988).

Eckbo and Langohr (1989) analyzed the impact of a regulation strengthening the disclosure requirements for French public tender offers on takeover premiums. They studied two situations: the change from a pre-regulation premium percentage over the market price to a post-regulation premium percentage for public companies and the change in premiums between the public and the private sector, which was not targeted by the regulations. In both situations, significantly higher transaction premiums were observed for public companies after the regulation.

Hangendroff, Hernando, Nieto and Wall (2012) investigated a sample of cross-border and domestic takeover transactions in the banking industry in the European Union during the decade 1997 to 2007.

They found that stricter bank regulation had the effect of lowering the acquisition premiums paid by banks. This study suggests that the decrease in premiums paid is due to the expectation of greater regulatory compliance expenses.

More recently, Cohen, Dey and Lys (2013) examined the correlation between a regulation endorsed by the US Congress in 2002, the Sarbanes-Oxley Act, and takeover premiums in the United States. The Sarbanes-Oxley Act was aimed at enforcing the corporate governance internal monitoring practices of US firms. This regulation caused firms to revise their management compensation practices and led to a decrease in risk-taking incentives and performance-linked compensation of CEOs. As a result, the level of investment undertaken declined, the number of mergers and acquisitions fell, and both firm operating performance and transaction premiums diminished.

\subsubsection{Method of Payment}

De La Bruslerie (2013) studied the relationship between the method of payment in mergers and acquisitions and the premium paid by the acquiring firm. He used a sample of European transactions that occurred between 2000 and 2010 and found a significant positive correlation between the percentage of payment in cash and the offer premiums.

In the United States, the choice of the method of payment is significantly related to the willingness of the target firm's shareholders to hold stock of their acquirer (Burch, Nanda and Silveri, 2012). When stock is offered to the target's shareholders, the option to defer taxes on capital gains and the amount deferred depends on the shareholders' willingness to hold the acquirer's stock. If the willingness to hold the acquirer's stock is high, a larger proportion of the offer will be paid in stock and the premiums will be smaller. Burch, Nanda and Silveri found a negative correlation between takeover premiums and the proportion paid in stock.

In addition, some factors have been found to affect the method of payment and, by deduction, would potentially be correlated with the takeover premium. Based on a study focusing on mergers and acquisitions in the Dutch market between 1996 and 2005, high growth target firms' shareholders prefer to be paid with equity, whereas shareholders of lower growth firms do not (Schauten and Swierigna, 2008). This study also found that the fraction of ownership is significantly related to the shareholders' method of payment preferences: shareholders with high ownership stakes prefer stock offers, whereas shareholders with intermediate ownership stakes prefer cash offers. This is explained by the control position of shareholders: since stock financing dilutes the proportion of voting rights and increases the risk of losing control, investors with high ownership stakes, who are not as concerned with the risk of losing control as investors with intermediate ownership stakes, prefer equity financing. Schauten and Swieringa also note that the size of transactions is related to the method of payment. Large deals tend to be financed with a higher proportion of stock, as opposed to small deals, which tend to involve a larger percentage of cash. This tendency is explained by the observation that bidders' unused debt capacity and liquid assets are insufficient to offer a greater proportion of cash in large deals. Acquisitions of targets within the same industry are likely to involve a greater proportion of stock compared to a cross-industry transaction. This finding is justified by the argument that shareholders are more likely to accept a stock offer when they know and understand the bidders' industry. Finally, asset acquisitions tend to involve cash offers, whereas stock acquisitions are likely to be financed with equity. Companies selling their assets prefer cash payments in order to pay back their shareholders.

The "signaling effect" is also believed to affect the choice of method of payment (Travlos, 1987). A takeover offer involving stock payment conveys negative information; the acquiring firm sends a signal to the marketplace. Cash offers indicate that the acquiring firm is confident in the potential for value creation from the transaction and also signals that the firm's stock might be undervalued. 
To summarize, the growth characteristics of target firms, ownership concentration characteristics, size, scope of the transaction, type of acquisition and "signaling effect" are significantly related to the choice of method of payment and could, since the method of payment is related to takeover premiums, affect acquisition premiums themselves.

\subsubsection{Merger Motives and Characteristics}

It has been demonstrated that the management motivation driving mergers and acquisitions is related to takeover premiums. Mergers justified by only one motive are a minority. Around $80 \%$ of mergers are associated with two motives or more (Nguyen, Sun and Yung, 2013). Some factors increasing or decreasing the premiums paid may coexist; it is therefore important to learn about the potential effects of acquisition motives on the premiums, in order to be able to build an expectation of the premiums based on the announced and observed motives.

Specific characteristics of the acquirer and target firm, such as the $\mathrm{P} / \mathrm{B}$ and $\mathrm{P} / \mathrm{E}$ ratios, or even the industry, are also observed to be linked to the merged firm's performance. Canina and Kim (2013) investigate the relationship between offer premiums and the change in performance for both acquiring firms and target firms. They found that takeover premiums are related to the change in performance measures (peer-adjusted revenues and peer-adjusted operating income) of acquiring firms, but not to those of target firms. However, the target firm's assets and activities are essential to improving the acquiring firm's performance characteristics (performance improvements due to synergies). Since changes in performance affect takeover premiums, and performance post-merger is related to target firms' assets and activities, we argue that target firms' assets and activities are related to takeover premiums.

A study of M\&A transactions in the banking industry in the decade between 1994 and 2005 examined the relationship between takeover premiums and the extent to which the acquiring firm is searching for growth. The research suggests that when a firm's organic growth is slow and it is dependent on external acquisitions for growth, there is a measurable factor called "desperation for growth", which is significantly related to takeover premiums (Haleblian, Kim and Sydney, 2011). The more desperate for growth the acquiring firm is, the higher the premium and the potential overpayment. This study also finds that the experience and expertise of the advisors in the transaction helps diminish the overpayment. However, the experience and expertise gained by the management of the acquiring firm from previous acquisitions is not significantly related to reductions in overpayments when the firm's desperation for growth is high.

Ismail (2011) enlarges the scope of the desperation for growth theory and finds that premiums paid are not explained by synergies and that overpayments are more common and larger in value when acquiring firms have low growth prospects. Premiums also tend to be larger when target firms have a strong performance record before the transaction, are large and have good potential for growth.

Svetina (2012) finds that public firms pay significantly higher premiums than private equity firms. He argues that efficiency motives, such as the potential cost cutting benefits of relocating resources (synergies), are the main driver of acquisitions for public firms. This type of acquisition is also called a "strategic takeover". As opposed to private equity buyers, who are not concerned with synergies, but consider several other investment motives, public firms are willing to pay a significantly larger premium in order to complete a transaction. If divergence of premiums paid by public and private equity firms is not explained by efficiency motives, an overpayment may have occurred.

Edminster and Walkling (1985) provide a range of evidence regarding takeover premiums and acquisition characteristics. First, they demonstrates that the higher the percentage ownership of the acquiring firm by the target firm that owns shares of the acquiring firm before a merger, the higher the takeover premium. In other words, if the target firm owns shares of the acquiring firm before a merger, the premium offered to shareholders in order to acquire the necessary stake for a controlling interest tends to be greater than when the target company is not a shareholder of the acquirer; that is, the percentage ownership in the acquiring firm by the target is negatively related to the bargaining power of the acquirer. The authors also investigate the correlation between takeover premiums and the presence of competitive bids. They find that in the presence of two or more bidders, the offer premiums were $30 \%$ higher on average than with a single bidder. This higher premium paid by the winning bidder is often referred to as the "winner's curse" (Eckbo, 2009). In order to win the bidding war, an acquirer is pushed to offer a higher premium to the target's shareholders than it would have offered in a scenario with no competitors; in a competitive bidding environment the winner is doomed to some form of overpayment. Edminster and Walkling also found that when the takeover is backed by a diversification motive-that is, the acquiring firm tries to enter a new market segment or commercialize new products or services, and uses external growth to build a conglomerate-takeover premiums tend to be 7\% lower than when firms stay within the same industry and rely on synergies or economies of scale to create value for shareholders. 
Hostile takeovers are takeovers in which the target firm's management is opposed to the transaction. As a result, the acquiring firm deals directly with the target firm's shareholders, usually through a tender offer or a proxy fight, in order to purchase their shares and obtain a controlling stake in the company. Potential targets' management can anticipate such hostile takeovers by implementing pre-offer takeover defenses such as poison pills or a staggered board or can adopt response defense mechanisms after a hostile offer has been made, such as finding a white knight, using greenmail or a crown jewel defense. Hirshleifer and Titman (1990) study the relation between hostile takeover bids and target firms' defense mechanisms. They fi nd that defense mechanisms can deter hesitant bidders by forcing the acquirer to pay a higher premium. Hostile takeovers have been linked to higher premiums than have friendly takeovers (Schwert, 2000).

The literature shows that takeover motive and firm properties -- such as the target firm's organic growth rate, the acquirer's desperation for growth, whether the acquirer is a public or private firm, and the percentage ownership of the acquirer's shares by the target prior to a bid announcement - have been found to be significantly related to acquisition premiums. These findings can help us develop our expectations for these premiums. Comparing these expectations with the actual premiums announced would allow us to provide an opinion on whether the premium is excessive, insufficient or fair.

\subsubsection{Corporate Governance}

Corporate governance is one of the most overlooked factors affecting takeover premiums. It is defined as the set of practices and processes that govern a corporation. Corporate governance addresses the agency problems that are inherent in the separation of ownership and management of operations; that is, the firm's managers and shareholders may have different objectives for the firm. At the heart of the corporate governance system, the board of directors makes decisions regarding the firm's policies and strategies. Its main purpose is to minimize the agency costs that arise because of the divergence in objectives between shareholders and managers. Gompers, Ishii and Metrick (2011) examined 1500 companies and created a "corporate governance index" to assess the strength of corporate governance for each firm in their sample. They found that firms with stronger shareholders rights had returns $8.5 \%$ greater than the returns of companies with limited shareholders rights, higher sales growth, lower capital expenditures and fewer corporate acquisitions.

Some characteristics of boards of directors are related to takeover premiums. Lima and Sanvicente (2013) investigated 188 firms in emerging markets and found that institutional investors would pay a premium of $28 \%$ greater than average for target firms with good corporate governance measures. This attests to the value of corporate governance to investors.

One of the tasks of the board of directors aiming at minimizing agency conflicts is to vote upon the CEO's compensation. Dorata and Jaggi (2006) investigated the hypothesis that the size of the premium in a transaction is related to the personal enrichment of CEOs. Their analysis of 646 mergers and acquisitions supported this hypothesis: the bid premiums were positively related to the difference in CEO cash compensation before and after the merger. It was also demonstrated that this effect was moderated when CEOs held shares of the acquiring firm and when acquiring firms conducted size-contraction changes. This shows that the board of directors' responsibility to set the CEO's compensation can have a significant effect on the value building activities undertaken by the CEO; stock based compensation encourages the CEO to make decisions in line with shareholders' interests, redoubling efforts in selecting targets and negotiating premiums. To ensure proper compensation packages, compensation committees are typically appointed by the board.

The CEO's personality and state of mind have also been found to influence the magnitude of takeover premiums, Excessive CEO self-confidence is referred to in the literature as CEO "hubris". Hambrick and Hayward (1997) defined four proxy variables to quantify CEO hubris and studied its relation to takeover premiums, as follows: the acquiring company's recent performance, recent media praise for the CEO, a measure of the CEO's self-importance, and a composite factor of all these variables. They concluded that there is a strong positive correlation between CEO hubris and takeover premiums, and that this relation is enhanced when the CEO is also the chairman of the board, the board lacks in vigilance or when there is a large proportion of inside directors on the board. This emphasizes the importance of having good corporate policies and the consequences attached to weak corporate governance systems.

Corporate governance exhibits some traits of behavioural bias. Zhu (2013) studied the effects of "group polarization" of the directors on takeover premiums. The outcome of Zhu's research shows that when directors have reasons to support relatively high premiums prior to board discussions, premiums after discussion are, on average, even higher than the pre-discussion level supported by individual directors. This group polarization also exists when directors are 
willing to support relatively low premiums before the board meeting, in which case board discussions result on average in a premium lower than the level expected before the meeting.

Further evidence of behavioral bias shows that interlocking boards and professional advisory firms are also related to takeover premium decisions. Haunschild (1994) examined 453 acquisitions that occurred between 1986 and 1993 and came to the conclusion that boards interlocked with other boards tend to pay a premium close to the ones paid by their interlock partners. Haunschild also found that firms using the same advisors tend to pay relatively similar premiums.

Before submitting an offer, acquirers can group and submit a single bid. This practice is known as "club bidding". Marquez and Singh (2013) studied club formations and found that club bidding could increase the takeover premium when the number of bidders is fixed and large. However, when bidders face entry costs, they are forced to optimize their decisions and this is reflected in lower observed premiums.

We found in the existing literature that many different factors derived from corporate governance were related to takeover premiums. In the next section, we expand our research to the broader term "management control" and define quality measurement factors to help understand whether premiums are justified.

\subsection{Measure of Management Control Quality}

Management control has been defined in various ways. Some refer to it as the extent to which management has control over business processes (Oviantari, 2014). Management control sometimes relates to the ability of the board of directors to control and monitor the company's management effectively. It can also be described as the (controlling) interest held by management or the equity ownership of management relative to outside shareholders. In this paper, management control will relate to both corporate governance and equity ownership.

We found in the existing literature (see above) that both corporate governance and firm equity ownership were related to takeover premiums. Alali, Anandarajan and Jiang (2012) emphasize the importance of considering firms' corporate governance by showing that corporate governance influences directly firms' bond and credit ratings, which, in turn, affect firms' cost of capital and valuation. As an example of the importance of corporate governance in investment decision making, a recent study found that portfolio managers of mutual funds in 37 countries worldwide tend to skew their investments towards firms with strong corporate governance practices (Praveen, 2014). In order to understand the roots of what influences takeover premiums, we focus our attention on examining what affects the quality of corporate governance and how equity ownership is related to management control quality.

\subsubsection{Properties of a "Good" Corporate Governance System}

Lima and Sanvicente (2013) created a scorecard system to assess the quality of corporate governance. They include in their research a wide variety of factors which we could group as the board of directors' characteristics, the disclosure policies, and shareholders' and investors' rights recognition. We shall examine factors affecting corporate governance quality beyond Lima and Sanvicente's paper.

\subsubsection{Board of Directors Quality Factors}

In a study of Malaysian publicly traded companies, corporate governance mechanisms, including board compensation and frequency of board meetings were found to be related to the effectiveness of innovation investments (Haat et al, 2010). Innovation investments are related to value creation for the firm, which translates into growth prospects and higher firm valuations. The authors found that the more frequent the board meetings, the better the corporate governance and the higher the quality of investment in innovation.

Davidson, Jiraporn and Kim (2008) examined the relationship between multiple directorships, board members sitting on other companies' boards and firm value. They found that when directors were sitting on several boards (referred to as "degree of directors' busy-ness"), the firm suffered a "diversification discount", harming its valuation. They also concluded that overcommitted directors could be harmful for the firm. Therefore, there is a fine line between directors who are overcommitted and might lack outside perspective and experience to make the best possible decisions for the firm, and overly busy directors who might neglect the importance of their seat on the board. Over busy-ness may result in low attendance rates at board meetings and poor contributions to decision making.

Deng and Lei (2014) also studied the relationship between multiple directorships and firm valuation. They chose to focus on publicly traded firms in Hong Kong. Deng and Lei found that there is positive correlation between the number of multiple directorships of dependent directors and firm value, which is due to the superior level of experience gained by directors who sit on more than one board. They also found that this correlation diminished when the directors' level of "busy-ness" increased. 
In the past, numerous researchers have investigated the relationship between CEO and board chair separation, and the effectiveness of the board (leading to higher firm valuations). Companies have been changing their corporate governance policies in order to separate the roles of the chair and CEO to comply with corporate governance best practices. The separation of the two positions has been found to facilitate the effective monitoring of top management, improve financial performance of the firm and reduce conflicts of interest (Syriopoulos and Tsatsaronis, 2012). However, Syriopoulos and Tsatsaronis' conclusions are balanced by those of Schmid and Zimmermann (2008), who argue that there is no significant correlation between firm valuation and $\mathrm{CEO} /$ chair duality. They add that the agency conflicts that arise when the roles are not separated can be offset by an adequate level of stock in the executive compensation package. In other words, even though separation of the CEO and chair is recognized as a sign of good corporate governance, no separation of the two roles does not necessarily mean poor corporate governance.

An important role of the board of directors is to monitor the firm's management to avoid fraud, encourage good management practices, ensure that the firm's strategic plan is being followed and, ultimately, to maximize shareholder wealth. Appointing different people as CEO and board chair tends to increase the independence and monitoring activities of the board. Bierman, Reutzel, Sirmon and Tuggle (2010) examined what factors led to changes in monitoring intensity. The season of the year was found to have a significant impact on the intensity of the monitoring practices. They also found that the impact of the past performance of the firm was significant: following a period of poor performance, boards tend to monitor firms' management more than after a period of good performance.

Abdel-Meguid, Dhahawy and Samaha (2014) studied the impact of non-audit committee corporate governance attributes on audit committee functionality. They found that the independence of the board had a significant effect on the quality of the audit committee among the firms studied. The more independent the board, the deeper the mandated scope of the audit and the higher the audit fees. Independence of the board is therefore considered a good corporate governance practice because it tends to improve the quality of the audit committees that are appointed.

Knyazeva, Knyazeva and Masulis (2013) examined the factors affecting board independence and the benefits of board independence for other attributes, using data for the period 1996 to 2006. They found that there is a significant correlation between the independence of the board of directors and the supply of qualified directors, which refers to the pool of directors available in the US at a given time. In other words, the quality of the board of directors can also be influenced by macro-economic conditions. For a board to be perceived as independent, $70 \%$ of board members need to be outside directors, but this percentage is subject to fluctuations in applied thresholds. Before stating that a board of directors is independent or not, the CEO-chair separation is analyzed as an important independence factor. According to Knyazeva et al, board independence has a positive impact on firm value, increases operating performance by setting up better controls over management and implementing more efficient strategies, increases the proportion of the CEO compensation package based on performance incentives and reduces CEO turnover. Board of directors' independence is therefore a major factor in determining board quality.

CEO turnover has been found to be correlated with the independence of the board (Laux, 2008). Although, we saw that fostering the adoption of an independent board was a good corporate governance practice and that it could help make objective value creating decisions, independent boards lack the information, which only the CEO possesses, to decide whether or not to retain the CEO. Higher CEO turnover was observed when the board had a high proportion of independent members. While there appear to be advantages to having an independent board of directors, it can result in information asymmetry. This information asymmetry can be reduced and decision making quality improved if the board is not completely independent from the firm's management. This view is supported by Kumar and Sivaramakrishnan (2008), who state that other types of agency problems might arise with a board of directors that is too independent.

The quality of the board of directors was examined by Keekley and Romancheck (2014). They argue that the tenure of board members is related to the quality of the board. Directors appointed for longer periods of time bring "invaluable experience" to the decision making process. Tenure of the board is a key factor to consider when assessing the corporate governance quality of a firm.

Cohen and Wang (2013) examined the relationship between boards of directors elected on a staggered basis (at different times with mandates greater than one year) and firm value. In line with their expectations, they confirmed the existence of a negative correlation between the election of boards on a staggered basis and firm valuation. One potential explanation might be that when corporate governance is poor, leading to lower valuations, companies with staggered boards tend to retain their directors for longer periods than boards elected on an annual basis. Cohen and 
Wang also suggest that directors' commitment to the firm tends to dissipate with longer mandates. Annual election of boards of directors may therefore be preferred.

Lo Bianco (2012) describes board self-assessment practices as number one among the " 10 best practices for boards". Flinn, Gill and Reissing (2005) developed a "Governance Self-Assessment Checklist", which could be used by boards of not-for-profit and public organizations to educate themselves about what constitutes a strong or weak governance system and to monitor their performance. They include 144 assessment items in their checklist, including performance monitoring factors, board development and decision making skills. They emphasize the importance of the self-assessment practices of the board in order to trigger improvements in all other categories reflecting best governance practices and higher value creation for the firm and stakeholders. Beyond the benefits of self-assessment, the adoption of such practices shows the commitment of the board to improve the firm's governance. This commitment to improvement itself is a reflection of higher board quality.

Blumsack (2006) encourages the adoption of communication practices self-assessment by the board of directors. The goal is to assess the frequency and effectiveness of the communication between the management of the company, the board of directors and the shareholders to order to minimize the costs associated with information asymmetry and make the firm more transparent and attractive to investors. Communication and self-assessment practices are looked upon as favorable procedures to implement.

Despite the importance of the adoption of self-assessment practices, only $21 \%$ of boards of public firms implement such procedures (Peabody and Stybel, 2005). Among the 21\%, assessments are commonly misused and the resulting outcomes depend on the data collection methodology and the respect of anonymity. However, self-assessment practices may be a good corporate behavior mostly because they show a commitment to improvement and self-monitoring of the board, and, to some extent, the efficiency of the practice.

\subsubsection{Disclosure Properties}

Disclosure of board decisions and process to the public is often referred to in the literature as board transparency. Board transparency is looked upon as a good corporate governance practice, which tends to enhance firm valuation (Hsiang-Tsai and Li-Jen, 2010). Hsiang-Tsai and Li-Jen also report that the type of compensation (percentage of the compensation package based on stock options) of directors influences the degree to which the board supports shareholders' interests and being transparent to the public. They also found that continuous education of the board is significantly related to transparency. Training directors and frequently reiterating what the role and duties of the board directors are increases transparency. Transparency is not only a good corporate governance practice according to Hsiang-Tsai and Li-Jen, but also reflects the alignment of the board with shareholders' interests.

Mazza, Norman, Rose and Rose (2013) studied the relationship between directors' alignment with shareholders' interests, directors' compensation package and transparency of the board when company management insists on implementing aggressive revenue recognition practices. They found that directors owning stock of the firm tend to put more effort into opposing such revenue recognition practices when transparency increases. However, increases in transparency do not significantly influence directors to attempt to stop aggressive revenue recognition when they do not own stock. Therefore, both stock compensation for directors and firm transparency are recognized as good corporate governance practices when joined together. The effect of transparency is limited when directors are not compensated with stock options.

Disclosure and transparency of board activities and decisions has been found to be related to the presence of women on the board of directors (Bernadi, Bosco and Larkin, 2013). Women who are sitting on the board are associated with increased transparency and ethical behavior of the board. The presence of women on the board could lead to significant improvements in the alignment of interests between directors and shareholders through diversity of thought and leadership.

Felo (2007) studied the relationship between corporate disclosure and firm transparency, and board adoption and support of codes of ethics. He found that boards adopting codes of ethics were significantly more transparent and disclosed more general information, financial information and board and management information. Therefore, the adoption of a code of ethics can be considered as a good corporate governance practice, reflecting the willingness of the board to be transparent and show its dedication to best serving shareholders' interests.

Chih-Liang, Her-Jium and Huimin (2010) documented the correlation between the disclosures made by the board of directors regarding directors and management compensation and value creation for the company. They found that when the board voluntarily discloses information regarding board and executive compensation, compensation packages tend to be set more fairly, reducing agency costs between management and shareholders, and creating value for shareholders. They also found that firms with a high proportion of independent board members disclose 
significantly more information about compensation practices than companies with a board of directors that is not significantly independent.

Cybinski and Windsor (2013) found that there is a positive correlation between the independence of the remuneration committee and firm's performance for large firms listed on the Australian stock exchange; when the remuneration committee is independent, the CEO's compensation package is aligned with firm performance, and performance is enhanced.

Chih-Liang et al's results are similar to those of Laksmana (2008). In addition, Laksmana found that the less frequent the board meetings and the fewer members on the board, the smaller the number of disclosures regarding compensation practices.

\subsubsection{Shareholders' Rights}

Beyond the roles and and responsibilities attributed to boards of directors, external shareholders influence board decisions to the extent of their voting rights. Cremers and Ferrell (2014) examined the restrictions on shareholders' rights over a thirty year period and assessed whether these restrictions are related to firms' market values. They found a negative correlation between restrictions of shareholders' rights and the firm's value. In other words, limiting shareholders' rights induces lower valuations. Hence the importance of considering the ownership structure of the firm and the extent to which shareholders can voice their interests to reduce agency costs.

Huang, Wang and Zhou (2013) studied the relationship between shareholders' rights and the level of accruals in earnings reports (earnings reporting quality). They found that when ownership is mostly outside of management, and when shareholders rights are strong enough to empower shareholders to replace the firm's executives, the earning reports were less aggressive. This result becomes insignificant when the level of "insider" ownership increases. Therefore, stronger shareholders' rights are a reflection of better corporate governance practices when there is a significant level of outside ownership.

Finally, Brown and Santiago-Castro (2011) researched Latin American emerging markets and identified a significant positive correlation between the expropriation of minority shareholders' rights and firm underperformance.

\subsubsection{Equity Ownership}

De La Fuente-Sabate, Delgado-Gracia and De Quevedo-Puente (2010) studied the relationship between companies' ownership structures and corporate reputations in civil law countries (also called European law countries). They found that when ownerships concentrated in a small number of shareholders, corporate reputation is diminished, whereas widely distributed ownership enhances reputation. They also found that in common law countries such as the US or the UK, institutional ownership reinforces company reputation. Whether a country is a common law country or a civil law country might affect the choice of relationship between ownership structure and company reputation.

Farag, Mallin and Ow-Yong (2014) examined the relationship between the extent of venture capital ownership and the reputation of the venture capitalists, and the quality of the corporate governance of the firm. They used a sample of 271 companies listed on the UK Alternative Investment Market to demonstrate that venture capitalists added expertise and experience to firms in which they had an equity stake. They found that the ownership portion of the venture capital investment was positively correlated with the quality of the corporate governance of the firm. The value of the company also increased with improvements in the company's corporate governance. The venture capital firm brings experience and is confident enough, as a major outside controlling shareholder, to replace the company's executives and improve governance. A significant proportion of venture capital ownership may therefore be the source of improved corporate governance for the firm and add expertise to the firm's board.

$\mathrm{He}$ and $\mathrm{Su}$ (2012) studied the correlation between ownership structure and corporate governance of 744 firms in China, and the productive efficiency of these firms. They found that state ownership is negatively correlated with firm efficiency, with publicly owned firms and employee owned firms significantly more efficient.

Chung and Zhang (2011) examined the impact of corporate governance on institutional ownership in China. They found that when the quality of corporate governance is high, the fraction of the company's shares owned by institutions is higher. They explain this relationship by stating that institutions consider the corporate governance system of target companies before making investment decisions in order to minimize exit costs and meet fiduciary responsibilities. High institutional ownership in China would mean higher corporate governance quality than with little institutional ownership, and may lead to increased company valuations and higher potential premiums when the company becomes the target of an acquisition. 


\subsection{Limitations of the Literature}

In the literature summarized above, we saw that premiums are sometimes, but not always, associated with value destruction for the acquiring firm's shareholders. Depending on the parameters chosen, premiums can be explained by value creating or value destroying factors. Therefore, it was important to understand what factors were related to premiums, and which ones had a positive or negative impact on shareholder value.

There are also some important limitations in the literature that need to be addressed. First, the research covers different regions of the world. Some evidence comes from emerging markets such as Brazil, China, Malaysia, the Philippines and Thailand, while some comes from developed markets in Europe, Hong Kong and North America. Some findings in emerging markets might not be applicable in other nations due to differences in market structure, growth rates, regulations and so forth.

The existing literature has examined takeover premiums over four decades. There have been some significant changes in regulations, politics, technology and the economic growth of all countries of interest over this period. Therefore, the evidence in past studies needs to be updated to reflect current conditions.

The existing literature is also limited in scope. Studies focus too often on a single explanatory factor and fail to take into consideration the characteristics of the target firm. Researchers come up with findings related to the acquiring firm or the new firm post-merger, ignoring important parameters of the target firm prior to being acquired. The latter are important to consider as well.

The previous literature also fails to link management control to takeover premiums. Most studies focus on the correlation between corporate governance and firm performance, but do not extend their scope to include takeover premiums. Management control defined as a combination of several corporate governance variables and equity ownership allocation does not appear to have been linked to takeover premiums before.

\subsection{Research Questions}

The gaps in the literature identified in the previous section raise a number of questions, the first of which is as follows:

* What is the impact of management control of the acquiring firm, given the management control characteristics of the target firm, on takeover premiums?

With this question, we make a clear distinction between the management control characteristics of the acquiring firm and those of the target firm. In addition, we shall consider the properties of both the acquirer and the target at the same time, and investigate potential correlations with takeover premiums. Proxy variables, as identified earlier, are defined in the next section to quantify the "strength" of the management control of firms. We will also set thresholds to determine whether the management control of a firm is strong or weak.

This leads us to consider the following questions:

* If the management control measures of the acquiring firm are seen as "strong", and the management control measures of the target firm are seen as "weak", how is management control related to takeover premiums?

* If the management control measures of the acquiring firm are seen as "strong", and the management control measures of the target firm are seen as "strong" as well, how is management control related to takeover premiums?

* If the management control measures of the acquiring firm are seen as "weak", and the management control measures of the target firm are seen as "weak", how is management control related to takeover premiums?

* If the management control measures of the acquiring firm are seen as "weak", and the management control measures of the target firm are seen as "strong", how is management control related to takeover premiums?

This paper will also try to find new guidelines that are relevant to equity investors and point out significant features of management control to look at for investment purposes:

* What are the relevant outcomes for equity investors?

Having determined our research questions, we establish in Section 2 the scope of our study, the data collection and the analysis methodology. 


\section{Modelling and Empirical Methodology}

Section 2 starts by establishing our propositions based on evidence from the existing literature. Then we define the variables to be used in our analysis, determine our data collection methodology and measurement of the qualitative variables, and organize the stages of our data analysis.

\subsection{Hypotheses}

As noted earlier, a firm's management control can be defined in several ways. Some refer to it as the process of setting goals for management to achieve, or controlling and monitoring a firm's performance. Others define it as the degree of control management exercises over company employees. We interpret management control as referring to the quality of the way in which the firm is being managed. This is manifested in several variables directly related to corporate governance and a variable related to the ownership structure of the firm.

Diverse ownership structures entail diverse allocations of decision-making authority; hence the relevance of ownership structure in determining the quality of the way in which the firm is managed. Management control is a composite term reflecting the overall direction of several variables, which are described in the following section. The strength of the management control defines whether the underlying variables reflect the use of best management practices or not, and will be measured using an ordinal scale.

As previously reported, acquiring companies have been found to be willing to pay higher amounts for targets with above average corporate governance quality. These higher amounts are likely to stem from either overstated valuation assumptions (such as growth rate or merger implementation probability of success), which increase the value of the firm, or higher premiums paid (intangible value perceived by the acquirer's management). This suggests that the stronger the management control of the target company, the higher the takeover premium.

$\mathrm{H}_{1}$ : There is a positive correlation between the strength of the management control of the target firm and the takeover premium.

We are also interested in verifying that the stronger the management control of the acquiring firm, the more thorough will be management in researching targets and in negotiating deals, and therefore the lower the takeover premiums.

$\mathrm{H}_{2}$ : There is a negative correlation between the strength of the management control of the acquiring firm and the takeover premium.

In addition, we will investigate the relationship between takeover premiums and the strength of the management control of the acquiring firm, given the management control of the target firm. From $\mathrm{H}_{1}$ and $\mathrm{H}_{2}$, we would expect that when the acquiring firm's management control is strong and the target firm's management control is weak, the takeover premium is likely to be low.

$\mathrm{H}_{3}$ : The strength of the management control of the acquiring firm, given weak management control in the target firm, will be negatively related to takeover premiums.

Similarly,

$\mathrm{H}_{4}$ : Weak management control of the acquiring firm, given a target firm's strong management control, will be positively related to takeover premiums.

In a scenario where both the acquiring firm and the target firm have strong or weak management control, the correlation with takeover premiums is uncertain.

$\mathrm{H}_{5}$ : When both the acquiring and the target firm have similar management control ratings (on an ordinal scale), the relationship between management control of the acquiring firm, given the management control quality of the target firm, and the takeover premium is uncertain.

\subsection{Variables Defining Management Control}

As discussed earlier, the variables to be investigated can be divided into two categories: corporate governance quality factors and ownership structure variables. All of the following are corporate governance quality factors, with the exception of ownership concentration.

\section{Independence of the board:}

In the literature review above, independence of the board of directors was found to be a major factor in the assessment of corporate governance quality. An independent board of directors contributes to higher quality management control. 


\section{Chair and CEO separation:}

Best corporate governance practices suggest that the role of the board chair should not be assigned to the CEO of the firm (Carver, 2013). This separation increases the decision-making power of the independent directors and fosters decisions that are in the interests of shareholders. This, however, might not be true for all firms. Small capitalization or private family-owned firms often do not realize any value from this separation since board members may be the only shareholders of the firm. For firms in the medium to large capitalization range, the chair/CEO separation not only shows that the firm takes initiatives towards adopting best corporate governance practices, but also tends to improve the quality of the decisions made by the board. Therefore, it leads us to assume that the separation of the roles of CEO and board chair reinforces the quality of corporate governance.

\section{Board elected on an annual or staggered basis:}

Electing board members on a staggered basis is used as a takeover defense by some companies. When directors are elected at different times for a multi-year mandate, hostile takeover bidders are compelled to win multiple proxy fights and extend their takeover efforts over a number of years in order to take control of the company. Even though this practice discourages hostile takeovers and may increase directors' tenure, having a board of directors elected on a staggered basis has been shown to alter the commitment of board members and the quality of the decisions made, hence reducing firm value. In addition, companies with staggered boards tend to retain inefficient directors longer than firms opting for annual board elections. Therefore, annual elections contribute to higher quality management control.

\section{Multiple directorships:}

We saw in the literature review above that multiple directorships of independent board members could be beneficial for companies since directors sitting on more than one board bring valuable experience to the firm. However, a director who sits on too many boards might neglect their role in each firm. Therefore we conjecture that the effect of the multiple directorships of independent directors on corporate governance quality of firms follows an inverted U-shaped curve.

\section{Existence and evaluation of board self-assessment practices:}

Board self-assessment practices have been demonstrated to be associated with higher firm valuations for a number of reasons (Peabody and Stybel, 2005). First, self-assessment practices increase board members' awareness of their own behaviours. Second, feedback on the board and individual performance keeps members accountable for their objectives. Adopting and using self-assessment practices is also a way to signal to shareholders that the board of directors is willing to engage in activities targeted at increasing shareholders' wealth. Therefore, we expect that the adoption and frequent use of self-assessment practices is linked to good corporate governance.

\section{Frequency of board meetings:}

In the US, the Model Business Corporation Act, 1950, recommends board meetings be held at least annually. In 2002, the Sarbanes-Oxley Act reinforced the responsibilities of board members regarding the accuracy and transparency of financial reports. This act requires board meetings to be held on an annual basis and the filing of at least two financial reports a year, including one audited report. Holding additional meetings excluding non-independent directors is strongly recommended. Without the management of the firm, board members are able to express themselves without internal pressure and make decisions on a more independent basis. Therefore, we expect companies implementing this strategy to have stronger corporate governance practices.

\section{Board members' compensation packages and remuneration transparency:}

Agency problems may arise at the board level and create conflicts between shareholders and the board of directors. Directors may also be influenced by company management, especially when the role of CEO and chair are not separated. In order to align board members' interests with those of shareholders, directors' compensation packages may include deferred share units (DSUs). A fair compensation package, including stock options/DSUs, helps to align directors with the long term growth objectives of the company and is considered a good corporate governance practice. In addition, large companies have started to poll their shareholders on their views of board remuneration policy. These polls are sought by investors and are interpreted as a proxy variable for the firm's corporate governance quality. As well, as reported above, the transparency and voluntary disclosure of board compensation practices have been found to be positively correlated with the level of approval from shareholders, and therefore with good corporate governance. 


\section{Presence of women on the board:}

The presence of women on the board has been found to align the board with shareholders' interests. Women on boards have also been found to reduce the level of "group think" and improve the decision making process. Their presence on boards has been associated with more ethical decision making. Having a meaningful proportion of women sitting on the board is seen as a sign of good corporate governance.

\section{Shareholders' rights limitation:}

Limited shareholders rights have been associated with lower firm valuations. When shareholders are able to vote management out of its position, firm reporting quality is found to be higher (smaller accruals and less aggressive revenue recognition) than when such rights are not recognized. In addition, firms' valuations are higher. Limits on shareholders' actions are associated with underperformance compared to industry peers due to increased agency costs. Shareholder voting power is associated with better corporate governance and higher management control quality.

\section{Dual class stocks:}

Dual class stocks allocate different voting rights to share classes. Companies' original owners may choose to issue dual class stocks to retain significant decision-making power with a low percentage of equity ownership. The adoption of dual class stocks can be seen by investors as positive or negative. On the one hand, executives and founders have a longer term perspective on the firm's operations than external investors, who often have a short investment horizon. Management-owned shares (with enhanced voting rights) rarely change hands and allow the firm to retain long term shareholders through bullish and bearish times. These are positive views on the use of dual class stocks. On the other hand, dual class stocks restrain shareholders' rights. In family-owned firms, executives' relatives can be placed in a management position with no regard to their abilities to lead the firm. It also allows the management to make poor decisions without large consequences. Dual class stocks were found to underperform the market (Baulkaran, 2014). We therefore consider dual class stocks to contribute to reducing shareholders' rights and lower corporate governance quality.

\section{Supermajority votes:}

With a supermajority requirement, commonly between two thirds and $80 \%$ of shareholders must voice their agreement with a takeover in order for it to take place. Supermajority empowers shareholders and allows them to reject a takeover attempt or force potential acquirers to increase their bids (Pound, 1987). Therefore, the presence of a supermajority voting requirement should be positively related to takeover premiums.

\section{Ownership concentration:}

$\mathrm{Da}$ La Fuente-Sabate et al. (2010) found that companies benefited from widely distributed ownership as opposed to concentrated ownership regardless of their investors' profile. There is also evidence that management ownership aligns decision-making with shareholder' interests. In addition, management ownership increases executives' bargaining power and hence their ability to serve their own interests, such as demanding higher premiums. Therefore, ownership concentration may have a significant impact on companies' performance and takeover premiums. Concentration of ownership in the hands of the company's management should enhance the firm's corporate governance quality up to some level of ownership, where additional ownership concentration begins to have a negative impact on corporate governance quality.

\subsection{Data Collection and Empirical Methodology}

\subsubsection{Research Design}

As discussed earlier, numerous studies have examined the relationship between corporate governance quality and firm performance and between firm performance and takeover premiums. In this paper, we are exploring relationships between corporate governance and ownership status and takeover premiums.

Our explanatory variables and assumptions are based on the existing literature. This research design allows us to expand the scope of a subject that has been studied in the past. Based on previous research, we can formulate new expectations and propositions that have not been considered previously, with a view to uncovering some new relationships.

We use both descriptive statistics and regression analysis. Descriptive statistics (mean-variance analysis and mean-equality tests between series) allow us to check the specification of our model and compare the means of premiums in different scenarios. Regression analysis complements the inferences from the descriptive analysis by establishing relationships between explanatory and dependent variables. 
The data for some of these variables studied cannot be directly collected and require the use of proxy variables. For each measure, a dummy variable is used to quantify the qualitative measure. With measurements for these variables, we are able to assign a numerical score to the quality of the management control. Then we run regression analyses, looking for correlations between the management control scores of the companies in our sample and takeover premiums, in order to determine whether our propositions can be statistically validated.

\subsubsection{Sampling Design}

We collected a sample of forty-two transactions (eighty-one companies) extending over a four year period from January 2010 to December 2013. This time span allows us to draw conclusions based on recent market conditions. Ending our data collection in 2013 enables us to confirm the completion of transactions and remove aborted agreements from the sample.

We used the Lexis Nexis Database to access international publications, company directories and legal materials (mostly 8-K forms filed with the US Securities and Exchange Commission), to identify transactions that occurred between 2010 and 2013 and their corresponding payment premiums. For each company involved in a transaction as a target or bidder, we collected data regarding their corporate governance and directors' characteristics through Wharton Research Data Services (WRDS).

We learned from the existing literature that some significant relationships between variables found in a country might not be true in other regions of the world. Therefore, we focus our attention exclusively on the North American region. All eighty-one companies in our sample operate in North America (the United States or Canada) and are publicly traded on North American stock exchanges.

The transactions in the sample vary in size, ranging from US\$221 million to US\$29 billion with an average of US\$5.7 billion and a median of US\$3.4 billion. The collection of data was not subject to any size restrictions provided that the deals respected the above time and geographical requirements. In the existing literature, there was no clear distinction between firm size and the direction of the relationships with corporate governance variables. Therefore, there is no basis for restricting our sample to a certain size. However, it is worth noting that whether the firms are mid-cap or large-cap might have an impact in some variables.

To the extent the data availability allowed, the premiums in our sample correspond to the bid over the 15 day average closing price preceding the announcement. This average allows us to reduce any noise caused by rumours around the deal before its official details are released. In the few transactions for which this information is not available, we measured the premium based on the last available closing price before the announcement.

\subsubsection{Measurements}

The quality of the management control of firms is measured using a scorecard system. Each variable used to reflect the quality of the management control will score I when the best management practices are respected and 0 otherwise. By adding scores from each variable, we will get an overall score out of 12 . The higher the score, the higher the quality of the management control. We define an ordinal scale for target firms as follows:

$$
\begin{array}{llr}
\text { Overall score (out of 12) } & 0-6 & 7-12 \\
\text { Management control quality } & \text { Weak } & \text { Strong }
\end{array}
$$

The scale for acquiring firms is:

$$
\begin{array}{ccc}
\text { Overall score out of } 12 & 0-7 & 8-12 \\
\text { Management control quality } & \text { Weak } & \text { Strong }
\end{array}
$$

We explain our choice of score for weak and strong firms in section 3.1.1.

\section{Independence of the board directors:}

Knyazeva et al (2013) recommend that at least $70 \%$ of board members should be independent of the firm. This suggestion is justified by a demonstrated increased ability to make long term value creating decisions in line with shareholders' interests. However, Kumar and Sivaramakrishnan (2008) set an upper limit to the optimal proportion of independent directors sitting on the board. Boards "too independent" might suffer from asymmetry of information and not have sufficient insight into the company's operations to make relevant business decisions. Kumar and Sivaramakrishnan do not state an explicit upper limit percentage for best practice purposes, but here we define the upper limit to be $90 \%$

Scoring implication: companies with a proportion of independent directors on the board between $70 \%$ and $90 \%$ score 1 , otherwise 0 


\section{Chair and CEO separation:}

Boards appointing two different individuals as the chair of the board and the chief executive officer of the company align their structure with best corporate governance practices.

Scoring implication: companies with two different individuals appointed as CEO and chair score 1, otherwise 0 .

\section{Board elected on an annual or staggered basis:}

Directors elected as often as once a year tend be more committed to their responsibilities and make greater long term value creating decisions than directors elected on a staggered basis.

Scoring implication: firms with boards of directors elected annually score 1 , otherwise 0 .

\section{Multiple directorships:}

Directors sitting on several boards bring diversity and valuable experience to the board.

Scoring implication: firms with at least half of their board members sitting on more than one board score 1, otherwise 0 .

\section{Existence and evaluation of the board's self-assessment practices:}

The existence of self-assessment practices and the evaluation of these practices is information that is seemingly not available on a database. Therefore, we shall use a proxy variable. One of the direct benefits of board self-assessment is that it forces board members to adopt an exemplary attitude. The easiest way for directors to be recognized for their work is to attend board meetings. We assume that attending at least $75 \%$ of board meetings shows sufficient commitment from directors.

Scoring implication: firms with at least two directors attending less than $75 \%$ of the meetings score 0 , otherwise 1 .

\section{Frequency of board meetings:}

The more frequent the board meetings, the greater the involvement of the board. The Sarbanes-Oxley Act requires board meetings to be held on an annual or quarterly basis and the filing of at least two financial reports a year, including one audited report. In the State of Washington, boards must meet at least six times per calendar year and at least once every quarter, whereas regulators in Canada let boards choose the frequency according to firms' needs. Meetings of independent directors have been demonstrated to enhance the quality of the decision making process. We assume that governance quality is high when boards have the ability to call special meetings.

Scoring implication: Firms with the ability to call special meetings score 1, otherwise 0 .

\section{Board members' compensation packages and remuneration transparency:}

"Say on pay" votes were introduced in the US in 2011 by the SEC; at least one vote must be organized every three years. This rule allows shareholders to voice their level of satisfaction with remuneration policies and golden parachutes. However, board members' remuneration packages are reviewed annually and their effectiveness may not be reflected in "say on pay" votes. A positive relationship between firm performance and the independence of remuneration committees has been demonstrated for large ASX 300 companies (Cybinski and Windsor, 2013). Therefore, in order to measure the efficiency and the extent of the communication around remuneration packages, we use the following proxy variable: the independence of the chair of the remuneration committee.

Scoring implication: firms which have an independent chair of the remuneration committee score 1 , otherwise 0.

\section{Presence of women on the board:}

The higher the proportion of women on the board, the stronger the corporate governance of the firm. Bernadi, Bosco and Larkin (2013) found that firms which had 33\% women or more on their board had significantly higher chances of appearing on the "World's Most Ethical Companies" list (Ethisphere Magazine). We round down to 30\% the proportion of woman on the board that is necessary for the company to be considered to have superior governance.

Scoring implication: companies with women representing at least $30 \%$ of board members score 1 , otherwise 0 .

\section{Shareholders' rights limitation:}

Strong shareholders' rights relates to shareholders having significant voting power over the firms' management; shareholders with strong rights are able to influence decision-making and change the firm's management when necessary. As discussed earlier, Gompers et al. (2001) developed a shareholders' rights strength index combining several relevant variables. They published a list of companies and their corresponding shareholders' rights scores to be used by anyone for further research. Their scores, available until 2006, do not cover our time frame and therefore 
cannot be used reliably in this research. In order to measure shareholders' rights, we use three proxy variables, the first of which is majority vs plurality vote (the others, dual class stock and supermajority votes, are described next). More and more firms are choosing majority voting over plurality voting. Adopting majority voting empowers shareholders to reject propositions that are not optimal for the firm (Cai, Garner and Walkling, 2013) or to have more power over the election of board members. Majority voting contributes therefore to higher corporate governance quality.

Scoring implication: firms with a majority voting policy score 1 , otherwise 0 .

\section{Dual class stocks:}

As discussed earlier, the dual class stocks limit shareholders' rights and concentrate the power in the hands of a certain class of shareholders. Dual class stocks do not contribute to higher corporate governance quality.

Scoring implication: firms without dual class stocks score 1, otherwise 0.

\section{Supermajority votes:}

A supermajority voting policy is a takeover defense mechanism. It ensures that takeovers are in alignment with shareholders' interests.

Scoring implication: firms with a takeover supermajority voting policy in place score 1 , otherwise 0 .

\section{Ownership concentration:}

The existing literature shows that management ownership reduces agency conflicts between shareholders and management. It also indicates that widely distributed ownership benefitted companies' reputations, whereas concentrated ownership was detrimental to companies' reputations. As a proxy variable for the ideal distribution between management ownership, we look at the proportion of board members who own between 1 and $5 \%$ of the voting power.

Scoring implication: firms with at least $10 \%$ of board members who each own between 1 and $5 \%$ of the voting power score 1 , otherwise 0 .

\subsubsection{Cross-sectional Data Analysis}

This data analysis serves the purpose of understanding what constitutes and justifies takeover premiums by responding to our previous propositions. Our analysis is divided into two sections:

\section{* Descriptive statistics.}

We first make use of descriptive statistics to complete an analysis of the management control scores of acquiring and target firms in order to explain the cut-off chosen between the strong and weak management control ranges.

Before using regression analysis, we also want to check whether there is a significant difference between the management control scores of acquirers in the following two situations:

* Targets' management control is weak

* Targets' management control is strong

This analysis allows us to determine whether conditional regressions should be run to validate our hypotheses.

We then use descriptive statistics to look for significant differences in premium sizes under four scenarios:

* Acquiring firms have strong management control scores whereas those of targets are weak

* Acquiring firms have weak management control scores whereas those of targets are strong

* Acquiring and target firms both have strong management control scores

* Acquiring and target firms both have weak management control scores

We run mean equality tests between the premiums in each scenario and premiums in our unconditioned sample. Through these tests, we seek confirmation of our hypotheses.

\section{* OLS Regressions}

We are using dummy variables in order to quantify the qualitative variables described above. Table 1 summarizes the explanatory $(*)$ and dependent $(* *)$ variables. 
Table 1

\begin{tabular}{ll}
\hline Variable description & Name used in analysis \\
Takeover premium** & PREM \\
Independence of the board* & IND \\
Chairman and CEO separation* & CHAIRCEO \\
Board elected on an annual basis* & ANNUALIST \\
Multiple directorships* & MD \\
Existence and evaluation of the board & SA \\
self-assessment practices* & \\
Frequency of board meetings* & \\
Board members' compensation packages & FREQUENCY \\
and remuneration transparency* & \\
Presence of women on the board* & COMPENSATION \\
Shareholders' rights limitation* & \\
Dual class shares* & WOMEN \\
Supermajority votes* & RIGHTS \\
Ownership concentration* & DUALCLASS \\
Management control score* & SUPERMAJORITY \\
& OC \\
& MCSCORE \\
\hline
\end{tabular}

Our empirical models, (1) and (2), are estimated using ordinary least squares.

$$
\begin{gathered}
\text { PREM }=\beta_{\mathrm{o}}+\beta_{1} \text { IND }+\beta_{2} \text { CHAIRCEO }+\beta_{3} \text { ANNUALIST }+\beta_{4} \text { MD }+\beta_{5} \text { SA }+\beta_{6} \text { FREQUENCY }+ \\
\beta_{7} \text { COMPENSATION }+\beta_{8} \text { WOMEN }+\beta_{9} \text { RIGHTS }+\beta_{10} \text { DUALCLASS }+\beta_{11} \text { SUPERMAJORITY }+ \\
\beta_{12} \text { OC }+\varepsilon \\
\text { PREM }=\beta_{o}+\beta_{1} \text { MCSCORE }+\varepsilon
\end{gathered}
$$

MCSCORE is the sum of all scores obtained for each independent variable. Two firms can have the same management control score and different corporate governance characteristics. For each hypothesis we examine the explanatory power of both cumulative management control scores and individual explanatory variables.

We start by examining the validity of $\mathrm{H}_{1}$ by regressing equation (1) using the management control values for target firms. We assess the significance of each variable and look at the direction in which the explanatory variables are related to premiums. Then, we regress (2) using data for target firms as well, and compare the overall results with those of the first regression.

We repeat the regression of equations (1) and (2), but this time using data for acquirers. We are seeking here to validate $\mathrm{H}_{2}$.

In the third section of our regression analysis, we take a conditional perspective on our data. We run four additional regressions to uncover potential relationships between acquirers' management control scores, and, alternatively, various combinations of explanatory variables and takeover premiums, given the management control strength of target firms. Since, as explained below, we uncover in the descriptive analysis that the management control score of acquiring firms, when the target's MCSCORE is weak, is significantly different from the acquirer's MCSCORE when the target's MCSCORE is strong, we use these regressions to check for changes in the strength, direction and significance of relationships in situations with varying characteristics of targets.

\section{Data Analysis and Discussion}

In this section, we first outline the results of our descriptive statistical analysis and then interpret our findings. 


\subsection{Descriptive Statistics}

\subsubsection{Management Control Scores Analysis}

We first conduct an analysis of the management control scores of target firms and acquiring firms in order to validate the cut-off between a strong and weak management control score.

Table 2. Target firms' statistics

\begin{tabular}{ll}
\hline & MCSCORE \\
Mean $\left(\mu_{1}\right)$ & 7.047619 \\
Median & 7.000000 \\
Maximum & 11.00000 \\
Minimum & 4.000000 \\
Std. Dev. & 1.591937 \\
Skewness & 0.472083 \\
Kurtosis & 2.629388 \\
Jarque-Bera & 1.800403 \\
Probability & 0.406488 \\
Observations & 42 \\
\hline
\end{tabular}

Table 3. Acquiring firms' statistics

\begin{tabular}{ll}
\hline & MCSCORE \\
Mean $\left(\mu_{1}\right)$ & 8.119048 \\
Median & 8.000000 \\
Maximum & 11.00000 \\
Minimum & 5.000000 \\
Std. Dev. & 1.328898 \\
Skewness & -0.220159 \\
Kurtosis & 3.307166 \\
Jarque-Bera & 0.504405 \\
Probability & 0.777087 \\
Observations & 42 \\
\hline
\end{tabular}

The mean of the management control scores of acquiring firms is higher than the mean of those of target firms. We confirm this observation by running a test of equality of means between the two management control series. At the $1 \%$ significance level, we reject the hypothesis that $\mu_{1}=\mu_{2}$.

This test shows that acquiring firms have on average higher management control scores than target firms. From this observation, we found it appropriate to adapt the cut-off between strong and weak management control. We set two different ranges for acquiring firms and target firms in order to better reflect the weakness or strength of the management control score of firms within their specific category (target group vs. acquirer group).

\subsubsection{Conditional Management Control Analysis}

We seek to uncover whether the management control scores of acquiring firms are significantly different when corresponding targets have strong or weak management control scores.

We run a mean equality test on two series of acquirers' management control scores, with strong management control scores of targets for the first series and weak management control scores of targets for the second. We find the difference to be significant at the $10 \%$ level and reject the null hypothesis of equality of means, albeit based on a sample of only 18 observations.

\subsubsection{Scenario Descriptive Analysis}

We examine four scenarios looking for significant changes in takeover premiums, as follows: 
* Acquiring firms have strong management control scores, whereas those of targets are weak (1)

* Acquiring firms have weak management control scores, whereas those of targets are strong (2)

* Acquiring and target firms both have strong management control scores (3)

* Acquiring and target firms both have weak management control scores (4)

But first let us look at the statistics for all premiums in our sample:

Table 4

\begin{tabular}{ll}
\hline & PREM \\
Mean & 0.323881 \\
Median & 0.285000 \\
Maximum & 0.690000 \\
Minimum & 0.037000 \\
Std. Dev. & 0.167207 \\
Skewness & 0.492891 \\
Kurtosis & 2.475901 \\
Jarque-Bera & 2.181278 \\
Probability & 0.336002 \\
Observations & 42 \\
\hline
\end{tabular}

With scenario (1), we expect the average of premiums, given strong acquirer management control and weak target management control, to be significantly smaller than the sample mean. We note that the premium, $u_{-}=0.25$, is lower than the overall sample mean.

We run a mean equality test between the mean of premiums obtained in this scenario and the mean of premiums in our sample. This test resulted in a significantly lower mean when scenario (1) occurred than the sample average at the $10 \%$ level, though at ten observations the number of transactions is very small. In other words, when acquiring firms have strong management control ratings and target firms have weak management control ratings, takeover premiums are significantly lower than the mean of our sample.

We expect scenario (2) to reflect a higher premium average than the sample average. The average of takeover premiums under condition (2) is 0.36 , which is slightly higher than the sample average. We run a mean equality test on these two series of premiums. The test's null hypothesis that the two series' means are equal cannot be rejected, though the sample size, at five, is very small.

From $\mathrm{H}_{5}$, we are uncertain of the direction in which premiums vary when both the acquiring and target firms share the same management control classification. Under scenario (3), the mean of the premium is equal to 0.34 , slightly above the sample 0.32 mean. These two means are not significantly different from each other. This result confirms our expectations, albeit based on only nineteen firms.

The outcome of scenario (4), with both the acquiring and target firm exhibiting weak management control characteristics, is uncertain as well. The mean premium for scenario (4) is 0.31 . The results of the mean equality test show no significant differences in means between the sample premiums and the premiums when scenario (4) occurs. This result aligns with our expectations, again with a small sample of only seventeen observations.

\subsection{Regression Results}

\subsubsection{General Comments}

The independent variables SA and COMPENSATION exhibited perfect collinearity and were therefore removed from equation (1). Our sample data for these variables, which were collected directly from the WRDS database, scored 1 for every observation in our sample. In addition, every director sitting on the board of the companies in our sample was absent from at most $25 \%$ of board meetings, which is equivalent to attending at least three meetings per year when the company follows a quarterly meeting policy. In addition, the chairman of the compensation committee was an independent director in every company observed. These two features, directors' attendance at meetings and independence of the remuneration committee chair, are unanimously accepted in the literature as traits of high quality corporate governance. The mid-cap and large-cap companies gathered in our sample have all committed to these standards. 


\subsubsection{Results $\mathrm{H}_{1}$}

Our first hypothesis is examined by regressing takeover premiums on the exploratory management control variables of target firms. We seek to confirm that the higher the management control scores of target firms, the higher the takeover premiums. The variable DUALCLASS was removed from the equation for this regression in order to correct for perfect collinearity. None of the target firms in our sample had dual class shares. The estimated coefficients are as follows:

Table 5

\begin{tabular}{lcc}
\hline Independent variable & Coefficient & t-statistic \\
& & \\
IND & 0.079629 & 1.187 \\
CHAIRCEO & 0.030914 & 0.536 \\
AANUALIST & -0.045745 & -0.829 \\
MD & 0.124756 & $2.156^{*}$ \\
FREQUENCY & -0.027075 & -0.415 \\
WOMEN & -0.078686 & -1.119 \\
RIGHTS & -0.087282 & -1.413 \\
SUPERMAJORITY & 0.086935 & 1.299 \\
C & 0.265201 & 2.948 \\
\hline
\end{tabular}

* significant at $5 \%$

With a coefficient of $12.5 \%$, the variable MD is significant at the $5 \%$ level and positively related to takeover premiums. The coefficient is consistent with our hypothesis.

The second regression focuses on the relationship between the aggregated management control scores of target firms and takeover premiums. This regression differs from the previous one in that two companies can have different values for individual variables, and still have the same management strength score. This allows for variations in the relationship between takeover premiums and the management control features of acquiring companies.

The coefficients are shown in the table below:

Table 6

\begin{tabular}{lll}
\hline Independent variable & Coefficient & t-statistic \\
MCSCORE & -0.001 & -0.0075 \\
C & 0.333 & 2.774 \\
\hline
\end{tabular}

There is no relationship between the management control score of target firms and takeover premiums.

4.2.3 Results $\mathrm{H}_{2}$

Our second set of regressions focuses on the relationship between the independent management control variables of acquiring companies and takeover premiums. The following coefficient values were obtained for equation (1):

Table 7

\begin{tabular}{lll}
\hline Independent Variable & Coefficient & t-statistic \\
IND & -0.098 & -1.563 \\
CHAIR CEO & 0.031 & 0.531 \\
ANNUALIST & 0.058 & 0.903 \\
MD & -0.058 & -0.798 \\
FREQUENCY & -0.100 & -1.437 \\
WOMEN & 0.069 & 1.152 \\
RIGHTS & 0.104 & 1.584 \\
DUAL CLASS & 0.004 & 0.029 \\
SUPERMAJORITY & 0.091 & 1.498 \\
OC & 0.041 & 0.569 \\
C & 0.31 & 1.806 \\
\hline
\end{tabular}


These coefficients correspond to the impact of scoring 1 in each variable on takeover premiums. For example, an acquiring firm with between 70 and $90 \%$ percent of independent directors on its board (IND) is likely to pay a premium $9.8 \%$ lower than a company which does not meet this criterion. $\mathrm{H}_{2}$ states that we expect takeover premiums to be negatively related to the management control strength of acquiring firms in this regression. Only three dependent variables, measuring the proportion of board members who are independent (IND), the proportion of directors holding multiple directorships (MD) and the proxy variable measuring the frequency of board meeting (FREQUENCY) have negative signs, but none are statistically significant. The other variables have positive coefficients, but they are not significant either.

We also regressed the takeover premium on the accumulated management control score (MCSCORE), and obtained the following:

Table 8

\begin{tabular}{cll}
\hline Independent variables & Coefficient & t-statistic \\
MCSCORE & 0.006 & 0.319 \\
C & 0.272 & 1.667 \\
\hline
\end{tabular}

The MCSCORE coefficient for acquiring firms, score is statistically insignificant, suggesting, once again no relationship with takeover premiums.

\subsubsection{Results $\mathrm{H}_{3}$ and $\mathrm{H}_{4}$}

The next regression estimates the relationship between the management control explanatory variables of acquiring firms and takeover premiums when target firms belong to the weak management control group. Every observation in our sample scored 1 for the dual class variable. We therefore, once again, removed the DUALCLASS variable. The estimated coefficients follow:

Table 9

\begin{tabular}{lll}
\cline { 2 - 3 } Independent variables & Coefficient & t-statistic \\
IND & -0.036 & -0.452 \\
CHAIRCO & -0.118 & -1.470 \\
ANNUALIST & -0.087 & -1.110 \\
MD & -0.169 & $-2.078^{*}$ \\
FREQUENCY & 0.085 & 0.968 \\
WOMEN & 0.025 & 0.296 \\
RIGHTS & 0.143 & 1.711 \\
SUPERMAJORITY & 0.142 & 1.662 \\
OC & 0.075 & 0.696 \\
C & 0.323 & 2.469 \\
\hline
\end{tabular}

* $\quad$ significant at $10 \%$

The variable MD is significant at the $10 \%$ level. With a coefficient of -0.169 , MD supports our expectation of a negative relationship between acquirers' management control and takeover premiums.

Similar to the previous cases, we also regress takeover premiums on the management control scores of acquiring firms given weak target firms' management control scores. We obtain the following results:

Table 10

\begin{tabular}{lll}
\hline Independent variable & Coefficient & t-statistic \\
MCSCORE & -0.004 & 0.856 \\
C & 0.335 & 0.100 \\
\hline
\end{tabular}

The MCSCORE variable is not significant, based on a sample of only 18 observations.

We also run a regression to test whether takeover premiums are related to management control variables of acquiring firms given strong target management control. The regression results are presented below: 
Table 11

\begin{tabular}{lll}
\hline Independent variable & Coefficient & t-statistic \\
IND & -0.146 & -1.440 \\
CHAIRCEO & 0.127 & 1.463 \\
ANNUALIST & 0.171 & 1.418 \\
MD & 0.084 & 0.634 \\
FREQUENCY & -0.136 & -1.275 \\
WOMEN & 0.042 & 0.483 \\
RIGHTS & 0.0136 & 1.135 \\
DUAL CLASS & -0.016 & -0.091 \\
SUPERMAJORITY & 0.032 & 0.341 \\
OC & 0.044 & 0.396 \\
C & 0.151 & 0.591 \\
\hline
\end{tabular}

In this regression, none of the coefficients are statistically significant. With 24 observations, the sample size is small.

The eighth regression focuses on the relationship between the accumulated management control scores of acquiring firms and takeover premiums given strong target management control. The results are presented next:

Table 12

\begin{tabular}{ccc}
\hline Independent variable & Coefficient & t-statistic \\
MCSCORE & 0.012 & 0.354 \\
C & 0.237 & 0.801 \\
\hline
\end{tabular}

Once again, the coefficients are not statistically significant, based on a sample of only 24 observations.

\subsection{Interpretation}

We first observed that the variable SA, measured by the attendance rate proxy variable, and COMPENSATION, which reflects whether the chair of the compensation committee is independent, both exhibited the same score for each observation in our sample. All firms involved in our sample of transactions had both directors who attended at least $75 \%$ of meetings and an independent chair of the compensation committee. These features, which contribute to higher corporate governance quality, seem to have become organizational standards for public firms in North America. Corporate governance is highly regarded by investors and these characteristics are essential for firms' stock to remain attractive. Therefore the self-assessment and compensation variables are not related to takeover premiums, but are standard features of public companies.

The variable DUALCLASS was removed from the regression of equation (1). All observations score 1 for the variable DUALCLASS, which means that none of the target firms in our sample have dual class shares outstanding. As discussed earlier, dual class shares limit shareholders' voting rights and concentrate a majority of voting rights in a share class that is rarely publicly traded. Therefore, dual class shares are deterrents to tender offers.

With a positive and significant MD coefficient, our first regression demonstrates that target firms in which we have directors who hold multiple directorships, are associated with higher takeover premiums. This result is in line with our proposition $\mathrm{H}_{1}$. We postulated that companies with a high proportion of board members sitting on several boards have better corporate governance than firms that do not meet this criterion and that, consequently, acquirers would be willing to pay higher premiums to acquire such firms. This could be explained by several factors. Directors who sit on more than one board can bring significant experience to firms; they may have previously been involved in M\&A transactions or have an outside perspective on business decisions. Also, sitting on several boards of publicly traded companies builds a strong reputation for both directors and firms. Companies are willing to pay a premium to acquire firms with reputably strong corporate governance. 
We tested $\mathrm{H}_{2}$ by regressing equation (1) using data for acquiring firms. We expected the strength of the management control of acquiring firms to be negatively related to takeover premiums. However, none of the explanatory variables were significant. Our model does not explain the relationship between acquirer's management control characteristics and takeover premiums.

We used descriptive statistics to analyze whether the management control scores of acquirers are statistically different in the following situations: when target firms' management control is strong and when target firms' management control is weak. Our test demonstrated that when targets' management control scores are strong, acquirers' management control scores are significantly higher. In other words, companies with weak management control are more likely to be acquired by companies with weak management control than are target firms with strong management control. Therefore, the relationship between acquirer management control and takeover premiums may vary with the strength of target management control.

This led us to run some conditional regressions. We reassessed the relationship between acquiring companies' management control strength and takeover premiums in the following two scenarios:

* Target firms' management control is strong

* Target firms' management control is weak

In the first scenario, we did not identify any significant relationships. However, the second scenario resulted in a significant negative MD coefficient of $-16.9 \%$. This conditional regression demonstrates that an acquirer with directors holding multiple directorships is related to significantly lower takeover premiums, given weak target management control. We previously argued that acquirers with strong management control should be negatively related to takeover premiums because acquirers with strong management control have the ability and skills to negotiate premiums and are more committed to finding the right target firm to acquire in order to optimize the implementation of their external growth strategies. This relationship only applies to the case when the target management control is weak, which could mean that an acquirer is able to influence the deal premium.

We used descriptive statistics to respond to the four scenarios presented earlier, which were as follows:

* Acquiring firms have strong management control scores whereas target firms have weak management control scores

* Acquiring firms have weak management control scores whereas target firms have strong management control scores

* Acquiring and target firms both have strong management control scores

* Acquiring and target firms both have weak management control scores

Our mean equality tests between premiums in each scenario and the sample mean of premiums generated some interesting outcomes. We first found that when acquiring firms' management control is weak, takeover premiums are significantly lower than the sample average. This confirms our expectation $\mathrm{H}_{3}$. This result can also be interpreted in relation to the bargaining power of firms; acquirers with strong management control have significantly greater negotiating power on transaction premiums than targets with weak management control.

We also found that when acquiring and target firms both share the same management control strength rating, strong or weak, the mean of the premiums is not significantly different from the sample mean of premiums. These results demonstrate that the relationship between management control and premiums is uncertain in these scenarios. When management control characteristics of acquiring and target firms are similar, and the direction of the impact of management control on takeover premiums differs between acquiring and target firms, neither acquiring nor target firms have a significantly stronger impact on premiums than the other. In other words, it seems that the influence of target firms' management control on premiums is as strong as the influence of acquiring firms' management control on premiums.

When target firms have strong management control scores, whereas acquirers have weak management control scores, our analysis demonstrates that premiums are not significantly different from the sample mean of premiums. This result does not confirm $\mathrm{H}_{4} \cdot \mathrm{H}_{4}$ reflects our expectation that premiums should be significantly higher than the sample average when targets' management control is strong and acquirers' management control is weak. Having found that strong acquirer management control when target management control is weak is significantly related to lower premiums, whereas weak acquirer management control when target management control is strong does not exhibit a significantly different premium, leads us to the conclusion that acquirers are not willing to pay premiums higher than average when targets' management control scores are strong nor premiums near the sample average when targets' 
management control scores are weak. In other words, when targets' management control is weak, acquirers negotiate premiums significantly lower than average. Additionally, when target management control is strong, acquirers are not willing to pay large premiums. An acquirer would pay less for weak target management control, but will not pay more for strong target management control.

We also use the MCSCORE to determine the existing relationships between aggregated management control scores and takeover premiums. However, the scorecard system does not show any significant relationships when used as the explanatory variables in our regressions.

\section{Managerial Implications}

In Section 4 we discuss potential applications of our findings, opportunities for improvement and directions for further research.

\subsection{Applications}

One purpose of this research is to inform the investment decision-making of equity investors. By studying the relationship between the management control characteristics of acquiring and target firms and takeover premiums, we try to understand what justifies premiums in order to be able to build an expectation of the size of a transaction premium. Then, comparing this expectation of the size of the premium to the actual premium paid allows us to determine whether the size of the premium is fair, too large or lower than expected.

We found that when the target's management control is weak and the acquirer's management control is strong, the premium is significantly lower than the sample average. This result can be used by investors as an initial step towards understanding which companies have not overpaid a premium. When looking at companies that have recently been involved in M\&A transactions, one can develop an expectation of the size of the premium relative to the industry mean as follows:

* Collect corporate governance and ownership structure data and calculate the management control scores of companies involved in transactions

* Select transactions in which the acquirer management control score is strong and the target management control score is weak.

* Compare the premium paid in the transaction to the industry mean premium.

* Draw conclusions according to the results in the third step.

If the premium paid is higher than or equal to the industry average, then the premium is not in line with our expectation and one should be aware of a potential value destroying overpayment. In this case, further research is needed to rationalize the premium paid before investing.

If the premium paid is lower than the industry average, then the payment is in line with our expectation and one can continue the analysis of other aspects of the deal and the newly formed firm in working towards an investment decision.

The above methodology can be looked at as a new company screening tool for equity analysts. When an analyst is researching a firm that results from a recent takeover, if the target firm's management control is strong and the acquirer's management control is weak, or if both acquiring and target firms have similar management control strength, then the premium is not expected to be significantly different from the industry average. If the premium paid is higher than the industry average, the analyst may be observing a potential value destroying overpayment. If the premium paid is lower than or equal to the industry average, then the premium passes this screen and analysts can be more confident that the premium size does not reflect an overpayment.

\subsection{Limits of the Study and Recommendations}

This study takes a new approach to understanding takeover premiums. It found some direct links between the management control characteristics of target and acquiring firms and takeover premiums. However, there are number of limitations to this research which we shall address, together with suggestions for new directions for study.

Second, in this study, we did not differentiate between different types of acquisition. Some acquisitions involve acquirers and targets from the same industry whereas others, called conglomerate mergers, involve two companies operating in different industries. Again, with more data, future studies could look at how the management control characteristics of firms affect takeover premiums when transactions are cross-industry deals and when they involve companies operating in the same industry. 
In addition, some strategic acquisitions are vertical (upward or downward), when acquirers buy companies operating at a higher or lower level of their supply chain, and some are horizontal, when bids target the acquirers' direct competitors or similar companies operating in different markets. In this case as well, making the distinction between types of mergers and acquisitions in the sample studied might unveil new insights into the relationship between management control characteristics and takeover premiums. We did not set any restrictions on the size of the deals in our sample, as long as they respected the defined geographical and time requirements. Therefore, transactions in our sample vary from slightly over USD200 million to over USD29 billion. One could break down the sample into transaction sizes and run separate regressions on subsets of data in order to uncover results more specific to each transaction size.

Another opportunity for improvement in this study is the number of observations in our sample. Our sample only includes 42 transactions with 81 companies. A larger sample would allow stronger conclusions.

We saw that some variables were not significantly related to takeover premiums and had limited explanatory power. Therefore, it would be interesting for future research to test additional variables. One could adapt the proxy variables to optimally reflect company management control; for example, we could add a board or CEO tenure variable. In addition, variables can be measured quantitatively instead of using a scorecard system; for example, we could use the number of women who sit on the board in regressions instead of scoring 1 when the proportion of women on the board was greater than $30 \%$. Similarly, we could use the number of directors exercising multiple directorships instead of scoring 1 when more than half of the board members sit on more than one board.

\section{Conclusion}

Our investigation of the existing literature related to takeover premiums, corporate governance and management control led to a number of conjectures. First, takeover premiums do not always reflect potential value creation for companies. Some takeover premiums are overpayments by the acquiring firm and destroy value to shareholders. Second, the existing literature provides evidence of relationships between specific firm attributes, such as the independence of directors who sit on a company board, and takeover premiums. Third, the ownership structure of the firm (management owned, institutionally owned or public vs private) is also related to firm performance and takeover premiums. These findings in previous work led us to study and attempt to fill the gap left in the literature between the corporate governance and ownership structure of firms (which we call management control) and takeover premiums. This way, we demonstrate a direct relationship between management control and takeover premiums, whereas in the past literature, variables were studied independently. By studying a sample of recent North American transactions, we found that target firms' proportion of directors holding multiple directorships is positively related to takeover premiums. We also found that given weak management control characteristics of target firms, the proportion of directors holding multiple directorships on acquirers' boards is negatively related to takeover premiums. In addition, we discovered that when target firms' management control is weak and acquirers' management control target is strong, takeover premiums are significantly lower than the sample average. Moreover, when target firms' management control is strong, and acquirers' management control is weak, and when both acquirers' and targets' management control is either strong or weak, takeover premiums are not significantly different from the sample mean. With these results, we are able to develop an expectation of the size of takeover premiums relative to the sample mean. By comparing the expectations with the actual premiums paid, we can develop a view on potential overpayments by acquiring firms. These findings are relevant to the literature because they extend the scope of studies previously conducted. In addition, our methodology and results can be used as a basis for further research. Our findings are also practical for investment analysis purposes and our model could be used as an additional tool to screen companies before conducting further analysis and making investment decisions. We encourage further research on the topic and recommend a more granular investigation of the data to increase the accuracy and the potential practical applications of the findings.

\section{References}

Abdel-Meguid, A., Dhawy, K., \& Samaha, K. (2014). Preliminary Evidence on the Relationship Between Corporate Governance Attributes and Audit Committee Functionality in Egypt: Beyond Checking the Box. International Journal of Effective Board Performance, 14,197-210. http://dx.doi.org/10.1108/CG-01-2011-0004

Alali, F., Anandarajan, A., \& Jiang, W. (2012, June). The Effect of Corporate Governance on Firms' Credit Ratings: Further Evidence Using Governance Scores in the United States. Accounting and Finance, 52, 291-312. http://dx.doi.org/10.1111/j.1467-629X.2010.00396.x 
Amit, R., Livnat, J., \& Zarowin, P. (1989). A Classification of Mergers and Acquisitions by Motives: Analysis of Market Responses. Contemporary Accounting Research, (Fall), 6, 143-158. http://dx.doi.org/10.1111/j.1911-3846.1989.tb00750.x

Ammann, M., Oesch, D., \& Schmid, M. (2011, January). Corporate Governance and Firm Value: International Evidence. Journal of Empirical Finance, 18, 36-55. http://dx.doi.org/10.2139/ssrn.1692222

André, P., Ben-Amar, W., \& Saadi, S. (2014, February). Family Firms and High Technology Mergers \& Acquisitions. Journal of Management and Governance, 18, 129-158. http://dx.doi.org/10.1007/s10997-012-9221-x

Annalisa, P., \& Sasson, B. (2013, July). The Impact of Corporate and Earnings Management on Stock Market Liquidity in a Highly Concentrated Ownership Capital Market. Journal of Accounting, Auditing \& Finance, 28, 292-316. http://dx.doi.org/10.1177/0148558X13492591

Baulkaran, V. (2014, February). Management Entrenchment and the Valuation Discount of Dual Class Firms. Quarterly Review of Economics \& Finance, 54, 70-81. http://dx.doi.org/10.1016/j.qref.2013.08.001

Bernadi, R.A., Bosco, S.M., \& Larkin, M.B. (2013, December). Does Female Representation on Boards of Directors Associate with Increased Transparency and Ethical Behaviour?. Accounting and the Public Interest, 13, 132-150. http://dx.doi.org/10.2308/apin-10374

Bierman, L., Reutzel, C.R., Sirmon, D.G., \& Tuggle, C.S. (2010, September). Commanding Board of Director Attention: Investigating How Organizational Performance and CEO Duality Affect Board Members' Attention to Monitoring. Strategic Management Journal, 31, 946-968. http://dx.doi.org/10.1002/smj.847

Blumsack, K. (2006). Assessment Closes Board/Administrator Communication Gap. Board \& Administrator, 23, 1-4. ISSN: 1525-7878. Available online at Business Source Complete, EBSCOhost.

Borisova, G., Brockman, P., Salas, J., \& Zagorchev, A. (2012, November). Government Ownership and Corporate Governance: Evidence from the EU. Journal of Banking \& Finance, 36, 2917-2934. http://dx.doi.org/10.1016/j.jbankfin.2012.01.008

Boubakri, N., \& Ghouma, H. (2010, October). Control/Ownership Structure, Creditor Rights Protection, and the Cost of Debt Financing: International Evidence. Journal of Banking \& Finance, 34, 2481-2499. http://dx.doi.org/10.1016/j.jbankfin.2010.04.006

Brown, C., \& Santiago-Castro, M. (2011, November). Corporate Governance, Expropriation of Minority Shareholders' Rights, and Performance of Latin American Enterprises. Annals of Finance, 7, 429-447. http://dx.doi.org/10.1007/s10436-009-0132-z

Bugeja, M., \& Walter, T. (1995, November). An Empirical Analysis of Some Determinants of the Target Shareholder Premium in Takeovers. Accounting and Finance, 35, 33-60. http://dx.doi.org/10.1111/j.1467-629X.1995.tb00285.x

Burch, T.R., Nanda, V., \& Silveri, S. (2012, September). Taking Stock or Cashing In? Shareholder Style Preferences, Premiums and the Method of Payment. Journal of Empirical Finance, 19, 558-582. http://dx.doi.org/10.1016/j.jempfin.2012.03.005

Cai, J., Garner, J., \& Walkling, R.A. (2013, June). A Paper Tiger? An Empirical Analysis of Majority Voting. Journal of Corporate Finance, 21, 119-135. http://dx.doi.org/10.1016/j.jcorpfin.2013.01.002

Canina, L., \& Kim, J.Y. (2013, November). Acquisition Premiums and Performance Improvements for Acquirers and Targets in the Lodging Industry. Cornell Hospitality Quarterly, 54, 416-425. http://dx.doi.org/10.1177/1938965513489770

Carver, J. (2013, November). Separating Chair and CEO Roles: A Flawed Debate. Board Leadership, 130, 1-7. Available online at Business Source Complete, EBSCOhost.

Cheung, Y., Stouraitis, A., \& Tan, W. (2010). Does the Quality of Corporate Governance Affect Firm Valuation and Risk? Evidence from a Corporate Governance Scoreboard in Hong Kong. International Review of Finance, 10, 403-432. http://dx.doi.org/10.1111/j.1468-2443.2010.01106.x

Chih-Liang, L., Her-Jiun, S., \& Huimin, C. (2010, November). Comprehensive Disclosure of Compensation and Firm Value: The Case of Policy Reforms in an Emerging Market. Journal of Business Finance \& Accounting, 37, 1115-1144. http://dx.doi.org/10.1111/j.1468-5957.2010.02213.x 
Chung, K.H., \& Zang. H. (2011, February). Corporate Governance and Institutional Ownership. Journal of Financial \& Quantitative Analysis, 46, 247-273. Retrieved from http://ssrn.com/abstract=1409222

Cohen, D., Dey, A., \& Lys, T. (2013). Corporate Governance Reform and Executive Incentives: Implications for Investments and Risk Taking. Contemporary Accounting Research, 30, 1296-1332. http://dx.doi.org/10.1111/j.1911-3846.2012.01189.x

Cohen, A. ., \& Wang, C.C.Y. (2013, December). How do Staggered Boards Affect Shareholder Value?. Journal of Financial Economics, 110, 627-641. http://dx.doi.org/10.1016/j.jfineco.2013.08.005

Collins, G. (2013). Corporate Ownership and Market Valuation in South Africa; Uncovering the Effects of Shareholding by Different Groups of Corporate Insiders and Outsiders. International Journal of Business Governance and Ethics, 8(3), 242-264. Retrieved from http://ssrn.com/abstract=2315225

Cremers, M., \& Ferrell, A. (2014, June). Thirty Years of Shareholders Rights and Firm Value. Journal of Finance, 69, 1167-1196. http://dx.doi.org/10.1111/jofi.12138

Cybinski, P., \& Windsor, C. (2013). Remuneration Committee Independence and CEO Remuneration for Firm Financial Performance. Accounting Research Journal, 26, 197-221. http://dx.doi.org/10.1108/ARJ-08-2012-0068

Davidson, W., Jiraporn, P., \& Kim, Y. (2008, June). Multiple Directorships and Corporate Diversification. Journal of Empirical Finance, 14, 418-435. http://dx.doi.org/10.1016/j.jempfin.2007.07.002

De La Fuente-Sabate, J.M., Delgado-Garcia, J.B., \& De Quevedo-Puente, E. (2010, November). The Impact of Ownership Structure on Corporate Reputation: Evidence from Spain. Corporate Governance: An International Review, 18, 540-556. http://dx.doi.org/10.1111/j.1467-8683.2010.00818.x

De La Bruslerie, H. (2013, June). Crossing Takeover Premiums and Mix of Payment: An Empirical Test of Contractual Setting in M\&A Transactions. Journal of Banking \& Finance, 37, 2106-2123. http://dx.doi.org/10.1016/j.jbankfin.2013.01.037

Deng, J., \& Lei, A. (2014, June). Do Multiple Directorships Increase Firm Value? Evidence from Independent Directors in Hong Kong. Journal of International Financial Management \& Accounting, 25, 121-181. http://dx.doi.org/10.1111/jifm.12017

Devers, C., Haleblian, J., McNamara, G., \& Yoder, M.E. (2013, December). Do They Walk the Talk? Gauging CEO and Director Confidence in the Value Creation Potential of Announced Acquisitions. Academy of Management Journal, 56, 1679-1702. http://dx.doi.org/10.5465/amj.2011.0555

Dorata, N.T., \& Jaggi, B. (2006). Association Between Bid Premium for Corporate Acquisitions and Executive Compensation. Journal of Accounting \& Finance, 21, 373-397. http://dx.doi.org/10.1177/0148558X0602100404

Duru, A., Wang, D., \& Zaho, Y. (2013, February). Staggered Boards, Corporate Opacity and Firm Value. Journal of Banking \& Finance, 37, 341-360. http://dx.doi.org/10.1016/j.jbankfin.2012.09.002

Eckbo, B. E. (2009, ebruary). Bidding Strategies and Takeover Premiums: A Review. Journal of Corporate Finance, 15, 149-178. http://dx.doi.org/10.1016/j.jcorpfin.2008.09.016

Eckbo, B.E., \& Langohr, H. (1989, October). Information Disclosure, Method of Payment and Takeover Premiums: Public and Private Tender Offers in France. Journal of Financial Economics, 24, 363-403. Retrieved from http://ssrn.com/abstract $=1480846$

Edmister, R.O., \& Walkling, R.A. (1985, January). Determinants of Tender Offer Premiums. Financial Analysts Journal, 41, 30-37. Retrieved from http://ssrn.com/abstract $=917880$

Elyasini, E., \& Jia, J. (2010, March). Distribution of Institutional Ownership and Corporate Firm Performance. Journal of Banking \& Finance, 34, 606-620. http://dx.doi.org/10.1016/j.jbankfin.2009.08.018

Farag, H., Mallin, C., \& Ow-Yong, K. (2014, March). Governance, Ownership Structure, and Performance of Entrepreneurial IPOs in AIM Companies. Corporate Governance: An International Review, 22, 100-115. http://dx.doi.org/10.1111/corg.12049

Felo, A.J. (2007). Board Oversight of Corporate Ethics Programs and Disclosure Transparency. Accounting and the Public Interest, 7, 1-25. http://dx.doi.org/10.2308/api.2007.7.1.1 
Ferrer, \& Rodiel, C. (2012, June). An Empirical Investigation of the Effects of Mergers and Acquisitions on Firms' Profitability. Academy of Accounting and Financial Studies Journal, 16, 31-55. Available online at Business Source Complete, EBSCOhost.

Flinn, R.J., Gill, M., \& Reissing, E. (2005). The Governance Self-assessment Checklist: An Instrument For Assessing Board Effectiveness. Nonprofit Management \& Leadership, (Spring), 15, 271-294. http://dx.doi.org/10.1002/nml.69

Gaughan, P.A. (2002), Mergers, Acquisitions, and Corporate Restructuring ( $3^{\text {rd }}$ ed.). New-York, Wiley.

Gompers, P. A., Ishii, J.L., \& Metrick, A. (2001, February). Corporate Governance and Equity Prices. Quarterly Journal of Economics, 118, 107-155. http://dx.doi.org/10.1162/00335530360535162

Haar, C., Hadj, A., Hassan, M., Rabi, M., \& Zulkafli, N. (2010, December). Corporate Governance, Innovation Investment and Firm Performance: Evidence from Malaysian Public Listed Companies. Economia: Seria Management, 13, 225-239. Retrieved form http://www.management.ase.ro/reveconomia/2010-2/2.pdf

Hagendoff, J., Hernando, I., Nieto, M.J., \& Wall, L.D. (2012, March). What do Premiums Paid for Bank M\&As Reflect? The Case of the European Union. Journal of Banking \& Finance, 36, 749-759. http://dx.doi.org/10.1016/j.jbankfin.2011.03.009

Haleblian, J., Kim, J., \& Sydney, F. (2011, March). When Firms are Desperate to Grow via Acquisition: The Effect of Growth Patterns and Acquisition Experience on Acquisition Premiums. Administrative Science Quarterly, 56, 26-60. http://dx.doi.org/10.2189/asqu.2011.56.1.026

Hambrick, D., \& Hayward, M. (1997, March). Explaining the Premiums Paid for Large Acquisitions: Evidence of CEO Hubris. Administrative Science Quarterly, 42, 103-127. http://dx.doi.org/10.2307/2393810

Hamerman, J. (2007). Do M\&A Premiums Matter? Investment Dealers' Digest, 73, 4-4. Retrieved from https://www.highbeam.com

Haunschild, P.R. (1994, September). How Much is that Company Worth?: Interorganizational Relationships, Uncertainty, and Acquisition Premiums. Administrative Science Quarterly, 39, 391-411. http://dx.doi.org/10.2307/2393296

He, X., \& Su, D. (2012, December). Ownership Structure, Corporate Governance and Productive Efficiency in China. Journal of Productivity Analysis, 38, 303-318. http://dx.doi.org/10.1007/s11123-011-0257-8

Hieu, V., \& Shantaram, P. (2013, June). Corporate Governance and Risk Taking in Pension Plans: Evidence from Defined Benefit Asset Allocations. Journal of Financial \& Quantitative Analysis, 48, 919-946. http://dx.doi.org/10.1017/S0022109013000227

Hirshleifer, D., \& Titman, S. (1990, April). Share Tendering Strategies and the Success of Hostile Takeover Bids. Journal of Political Economy, 98, 298-324. Retrieved from http://www.jstor.org/stable/2937667

Hitt, M.A., Krishnan, H. A., \& Park, D. (2007, July). Acquisition Premiums, Subsequent Workforce Reductions and Post-Acquisition Performance. Journal of Management Studies, 44, 709-732. http://dx.doi.org/10.1111/j.1467-6486.2006.00672.x

Hsiang-Tsai, C., \& Li-Jen, H. (2010, January). Board Supervision Capability and Information Transparency.

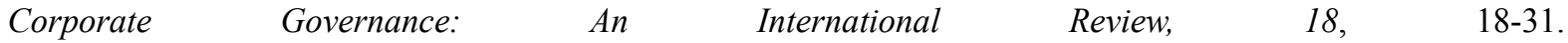
http://dx.doi.org/10.1111/j.1467-8683.2009.00779.x

Hu, Y., \& Zhou, X. (2008, October). The Performance Effect of Managerial Ownership: Evidence from China. Journal of Banking \& Finance, 32, 2099-2110. http://dx.doi.org/10.1016/j.jbankfin.2007.12.047

Huang, H., Wang, W., \& Zhou, J. (2013, March). Shareholder Rights, Insider Ownership and Earnings Management. Abacus, 49, 46-73. http://dx.doi.org/10.1111/j.1467-6281.2012.00390.x

Iannotta, G., Nocera, G., \& Sironi, A. (2007, July). Ownership Structure, Risk and Performance in the European Banking Industry. Journal of Banking \& Finance, 31, 2127-2149. http://dx.doi.org/10.1016/j.jbankfin.2006.07.013

Ismail, A. (2011). Does the Management's Forecast of Merger Synergies Explain the Premium Paid, the Method of Payment, and Merger Motives. Financial Management, (Winter), 40, 879-910. http://dx.doi.org/10.1111/j.1755-053X.2011.01165.x 
Jain, P.K., Rani, N., \& Yadav, S.S. (2012, January-June). Impact of Mergers and Acquisitions on Returns to Shareholders of Acquiring Firms: Indian Economy in Perspective. Journal of Financial Management \& Analysis, 25, 1-24. Available at Business Source Complete, EBSCOhost.

Keckley, J., \& Romanchek, B. (2014, January). Director Independence: A Focus on Board Tenure. NACD Directorship, 40, 75-75. Available at Business Source Complete, EBSCOhost.

Knyazeva, A., Knyazeva, D., \& Masulis, R.W. (2013, June). The Supply of Corporate Directors and Board Independence. Review of Financial Studies, 26, 1561-1605. http://dx.doi.org/10.1093/rfs/hht020

Kumar, P., \& Sivaramakrishnan, K. (2008, May). Who Monitors the Monitor? The Effect of Board Independence on Executive Compensation and Firm Value. Review of Financial Studies, 21, 1371-1401. http://dx.doi.org/10.1093/rfs/hhn010

Laamanen, T. (2007). Research Notes and Commentaries on the Role of Acquisition Premiums in Acquisition Research. Contemporary Accounting Research, (Winter), 25, 1147-1182. http://dx.doi.org/10.1002/smj.639

Laux, V. (2008, March). Board Independence and CEO Turnover. Journal of Accounting Research, 46, 137-171. http://dx.doi.org/10.1111/j.1475-679X.2008.00269.x

Lee, N., \& Lings, I. (2008). Doing Business Research--A Guide to Theory and Practice. London, Sage Publications.

Lima, B.F. and Sanvicente, A.Z. (2013). Quality of Corporate Governance and Cost of Equity in Brazil. Journal of Applied Corporate Finance, (Spring), 25, 72-80. http://dx.doi.org/10.1111/j.1745-6622.2013.12008.x

Lo Bianco, L. (2012, November). Top 10 Best Practices for Boards: A Lawyer's View. Nonprofit World, 30, 10-11. Retrieved from https://www.snpo.org/publications/sendpdf.php?id=1930

Madura, J., Ngo, T., \& Viale, A.M. (2012, February). Why do Merger Premiums Vary Across Industries and Over Time?. Quarterly Review of Economies \& Finance, 52, 49-62. http://dx.doi.org/10.1016/j.qref.2012.01.001

Marquez, R., \& Singh, R. (2013, May). The Economics of Club Bidding and Value Creation. Journal of Financial Economics, 108, 493-505. http://dx.doi.org/10.1016/j.jfineco.2012.12.001

Mazza, C.R., Norman, C.S., Rose, A. M., \& Rose, J.M. (2013, July). The Influence of Director Stock Ownership and Board Discussion Transparency on Financial Reporting Quality. Accounting, Organizations \& Society, 38, 397-405. http://dx.doi.org/10.1016/j.aos.2013.07.003

McCloskey Shanks, M. (2014, February). Order Approving the Acquisition of a Bank Holding Company, Merger of Banks, and Establishment of Branches. Federal Reserve Bulletin, 100, 13-27. Retrieved from https://www.federalreserve.gov/newsevents/press/orders/orders20131212a1.pdf

Melicher, R.W., \& Neilsen, F. (1973, March). A Financial Analysis of Acquisition and Merger Premiums. Journal of Financial \& Quantitative Analysis, 8, 139-148. http://dx.doi.org/10.2307/2330006

Mitchell, M.L., Mulherin, J.H., \& Weston, J.F. (2003). Takeovers, Restructuring, and Corporate Governance (4th ed.). New Jersey, Pearson Prentice Hall.

Newell, R., \& Wilson, G. (2002, September). A Premium for Good Governance. McKinsey Quarterly, 3, 20-23. Retrieved

from http://www.globalclearinghouse.org/wefhongkong/Docs/Premium\%20for\%20good\%20governance.pdf

Nguyen, H.T., Sun, Q., \& Young, K. (2012, November-December). Motives for Mergers and Acquisitions: Ex-Post Market Evidence from the US. Journal of Business Finance \& Accounting, 39, 1357-1375. http://dx.doi.org/10.1111/jbfa.12000

Okamuro, H., \& Shim, J. (2011, January). Does Ownership Matter in Mergers? A Comparative Study of the Causes and Consequences of Mergers by Family and Non-Family Firms. Journal of Banking \& Finance, 35, 193-203. http://dx.doi.org/10.1016/j.jbankfin.2010.07.027

Oviantari, I. (2014). Interaction Effect of Management Control Systems and Process Quality Management on Product Quality Performance. Annual International Conference on Accounting and Finance, 189-194. http://dx.doi.org/10.5176/2251-1997_AF14.43

Peabody, M., \& Stybel, L.J. (2005). How Should Board Directors Evaluate Themselves?. Sloan Management Review, (Fall), 47, 67-72. Available at Business Source Complete, EBSCOhost. 
Pound, J. (1987, October). The Effects of Antitakeover Amendments on Takeover Activity: Some Direct Evidence. Journal of Law \& Economics, 30, 353-367. Available at Business Source Complete, EBSCOhost.

Praveen, D. (2014, February). The Role of Corporate Governance in Foreign Investments. Applied Financial Economics, 24, 187-201. http://dx.doi.org/10.1080/09603107.2013.870650

Schauten, M.B.J., \& Swieringa, J. (2008, June). The Choice of Payment Method in Dutch Mergers and Acquisitions. ICFAI Journal of Mergers \& Acquisitions, 5, 26-59. http://dx.doi.org/10.2139/ssrn.1018899

Schmid, M.M., \& Zimmermann, H. (2008, April). Should Chairman and CEO Be Separated? Leadership Structure and Firm Performance in Switzerland. Schmalenbach Business Review, 60, 182-204. http://dx.doi.org/10.2139/ssrn.696381

Schumann, L. (1988). State Regulation ofTakeovers and Shareholder Wealth: The Case of New York's 1985 Takeover Statutes. Journal of Economics, (Winter), 4, 557-567. Retrieved from www.ftc.gov/

Schwert, G. W. (2000, December). Hostility in Takeovers; In the Eye of the Beholder. Journal of Finance, 55, 2599-2640. http://dx.doi.org/10.3386/w7085

Song, W., Wei, J., \& Zhou, L. (2013). The Value of 'Boutique' Financial Advisors in Mergers and Acquisitions. Journal of Corporate Finance, (April), 20, 91-114. http://dx.doi.org/10.1016/j.jcorpfin.2012.12.003

Sponbergs, P. (2007, March). Evaluation of Board Work in Fifteen Companies Belonging to the City of Stockholm. $\begin{array}{lllll}\text { Corporate } \quad \text { Governance: An International } & \text { Review, } & 15, & 159-172 .\end{array}$ http://dx.doi.org/10.1111/j.1467-8683.2007.00552.x

Svetina, M. (2012, October). Managerial Motives in Mergers: Propensity Score Matching Approach. Managerial \& Decision Economics, 33, 537-547. http://dx.doi.org/10.1002/mde.2565

Syriopoulos, T., \& Tsatsaronis, M. (2012). Corporate Governance Mechanisms and Financial Performance: CEO Duality in Shipping Firms. Eurasian Business Review, 2, 1-30. Available at Business Source Complete, EBSCOhost.

Travlos, N.G. (1987, September). Corporate Takeover Bids, Methods of Payment, and Bidding Firms' Stock Returns. Journal of Finance, 42, 943-963. http://dx.doi.org/10.2307/2328300

Zhu, D. (2013, July). Group Polarization on Corporate Boards: Theory and Evidence on Board Decisions about Acquisition Premiums. Strategic Management Journal, 34, 800-822. http://dx.doi.org/10.1002/smj.2039 